\title{
Do pelagic grazers benefit from sea ice? Insights from the Antarctic sea ice proxy IPSO $_{25}$
}

\author{
Katrin Schmidt ${ }^{1}$, Thomas A. Brown ${ }^{1,2}$, Simon T. Belt ${ }^{1}$, Louise C. Ireland ${ }^{3}$, Kyle W. R. Taylor ${ }^{4}$, Sally E. Thorpe ${ }^{3}$, \\ Peter Ward ${ }^{3}$, and Angus Atkinson ${ }^{5}$ \\ ${ }^{1}$ School of Geography, Earth and Environmental Sciences, University of Plymouth, Drake Circus, Plymouth PL4 8AA, UK \\ ${ }^{2}$ Marine Ecology and Chemistry, Scottish Association for Marine Science, Oban, Argyll PA37 1QA, UK \\ ${ }^{3}$ British Antarctic Survey, Natural Environment Research Council, High Cross, Madingley Road, Cambridge CB3 0ET, UK \\ ${ }^{4}$ Elementar UK Ltd, Isoprime House, Earl Road, Cheadle Hulme, Stockport SK8 6PT, UK \\ ${ }^{5}$ Plymouth Marine Laboratory, Prospect Place, The Hoe, Plymouth PL1 3DH, UK
}

Correspondence: Thomas A. Brown (thomas.brown@sams.ac.uk) and Simon T. Belt (s.belt@plymouth.ac.uk)

Received: 13 December 2017 - Discussion started: 18 December 2017

Revised: 1 March 2018 - Accepted: 2 March 2018 - Published: 4 April 2018

\begin{abstract}
Sea ice affects primary production in polar regions in multiple ways. It can dampen water column productivity by reducing light or nutrient supply, provide a habitat for ice algae and condition the marginal ice zone (MIZ) for phytoplankton blooms on its seasonal retreat. The relative importance of three different carbon sources (sea ice derived, sea ice conditioned, non-sea-ice associated) for the polar food web is not well understood, partly due to the lack of methods that enable their unambiguous distinction. Here we analysed two highly branched isoprenoid (HBI) biomarkers to trace sea-ice-derived and sea-ice-conditioned carbon in Antarctic krill (Euphausia superba) and relate their concentrations to the grazers' body reserves, growth and recruitment. During our sampling in January-February 2003, the proxy for sea ice diatoms (a di-unsaturated HBI termed $\mathrm{IPSO}_{25}, \delta{ }^{13} \mathrm{C}=-12.5 \pm 3.3 \%$ o) occurred in open waters of the western Scotia Sea, where seasonal ice retreat was slow. In suspended matter from surface waters, $\mathrm{IPSO}_{25}$ was present at a few stations close to the ice edge, but in krill the marker was widespread. Even at stations that had been ice-free for several weeks, IPSO $_{25}$ was found in krill stomachs, suggesting that they gathered the ice-derived algae from below the upper mixed layer. Peak abundances of the proxy for MIZ diatoms (a tri-unsaturated HBI termed HBI III, $\delta^{13} \mathrm{C}=-42.2 \pm 2.4 \%$ ) occurred in regions of fast sea ice retreat and persistent salinity-driven stratification in the eastern Scotia Sea. Krill sampled in the area defined by the ice edge bloom likewise contained high amounts of HBI III. As
\end{abstract}

indicators for the grazer's performance we used the masslength ratio, size of digestive gland and growth rate for krill, and recruitment for the biomass-dominant calanoid copepods Calanoides acutus and Calanus propinquus. These indices consistently point to blooms in the MIZ as an important feeding ground for pelagic grazers. Even though ice-conditioned blooms are of much shorter duration than blooms downstream of the permanently sea-ice-free South Georgia, they enabled fast growth and offspring development. Our study shows two rarely considered ways that pelagic grazers may benefit from sea ice: firstly, after their release from sea ice, suspended or sinking ice algae can supplement the grazers' diet if phytoplankton concentrations are low. Secondly, conditioning effects of seasonal sea ice can promote pelagic primary production and therefore food availability in spring and summer.

\section{Introduction}

Over the last four decades, sea ice has shown a rapid decline in areal coverage in polar regions. In the Arctic and parts of the Antarctic (e.g. Bellingshausen and Amundsen seas), sea ice concentrations are decreasing during both summer $(-10$ to $-13 \%$ per decade) and winter $(-2 \%$ per decade $)$ (Meier et al., 2017; Stammerjohn and Maksym, 2017), and current trends towards later autumn sea ice advance and earlier spring sea ice retreat are likely to continue in both hemi- 
spheres (Stammerjohn et al., 2012). Ecosystem responses to the loss in sea ice and co-occurring warming and freshening include changes in primary productivity, alterations in phytoplankton community structure, range shifts for zooplankton, benthic organisms and fish and decline in sea-ice-dependent sea birds and mammals (Li et al., 2009; Grebmeier et al., 2010; Constable et al., 2014). Understanding such climaterelated changes in structure and functioning of polar marine ecosystems is imperative for the management of their resource exploitation (Smetacek and Nicol, 2005).

Extended open water seasons have been suggested to lead to higher primary production in the polar oceans (Arrigo, 2017) and generate a negative feedback to climate change (Barnes and Tarling, 2017). Some satellite-derived chlorophyll $a(\operatorname{chl} a$ ) time series support this prediction (Arrigo et al., 2008), while others do not (Marchese et al., 2017). Along the western Antarctic Peninsula, warming and a reduction in sea ice extent between 1978 and 2006 led to two very different scenarios (Montes-Hugo et al., 2009). In the southern part, perennial sea ice was replaced by seasonal sea ice and the ice-free summer days translated into more favourable conditions for phytoplankton growth (e.g. increased light). In contrast, in the northern part, loss of seasonal sea ice led to a deepening of the upper mixed layer with less favourable light conditions for phytoplankton (Montes-Hugo et al., 2009). These observations illustrate the opposing effects that permanent and seasonal sea ice can have on primary productivity. While the former prevents phytoplankton blooms, the latter can promote them. Several processes associated with the seasonal retreat of sea ice are considered to "condition" the upper water column for phytoplankton blooms (Smetacek and Nicol, 2005). First, low-density meltwater can stabilise the surface layer and therefore enhance mean irradiance levels for phytoplankton (Smith and Nelson, 1986). Second, the release of trace elements from melting sea ice can alleviate iron limitation, which is a common feature in the open Southern Ocean (Lannuzel et al., 2010; Schallenberg et al., 2015). Third, some algae that thrive in sea ice also act as an inoculum for phytoplankton blooms (Smith and Nelson, 1986). This explains why the marginal ice zone (MIZ) is, on average, more productive than the permanently open waters of the Southern Ocean (Smith and Nelson, 1986; Tréguer and Jacques, 1992).

Chlorophyll $a$ concentrations in sea ice are not accessible to satellite observations and therefore primary production estimates rely on sparse in situ measurements and numerical models. Such data suggest that primary production in sea ice accounts for only small amounts of total annual production in polar waters: typically $2-10 \%$ in the Arctic and ca. $1-3 \%$ in the Southern Ocean south of $50^{\circ} \mathrm{S}$ (Arrigo, 2017). However, an important difference between phytoplankton and ice algae is that while the former is deeply mixed in the water column, sea ice provides a platform that retains the latter in the surface ocean where light levels can be sufficient for photosynthesis and net growth even during the dark season (Kottmeier and
Sullivan, 1987; Roukaerts et al., 2016). Therefore, ice algae supply an important autumn, winter and early spring carbon source to in-ice fauna, with subsequent transfer to the wider food web of ice-associated invertebrates, fish, seabirds and mammals (Ainley et al., 2017; Bluhm et al., 2017; Caron et al., 2017; Bester et al., 2017). Other merits of ice algae are their enrichment in polyunsaturated fatty acids that make them a high-quality food source (Søreide et al., 2010; Wang et al., 2014), while their tendency to aggregate and sink after being released from sea ice can be an important pathway of carbon export to the benthos (Riebesell et al., 1991; Renaud et al., 2007). Thus, the small contribution of ice algae to the overall primary production in the polar regions likely understates their ecological importance.

Dominant polar grazers such as calanoid copepods and euphausiids are adapted to the strong seasonality in primary production and the dynamic interface between ice and water (Smetacek and Nicol, 2005). Post-larval stages of these species biosynthesise large lipid stores, which enable them to survive long periods without food (Hagen and Auel, 2001). Some species remain active during winter (e.g. the Antarctic copepod Calanus propinquus and the Antarctic krill Euphausia superba) and can be found under sea ice feeding on ice algae or heterotrophs, if available (Atkinson and Shreeve, 1995; Flores et al., 2012a; Schmidt et al., 2014). In other species, e.g. the Arctic Calanus hyperboreus and C. glacialis together with the Antarctic Calanoides acutus, the life cycle is closely coupled to the bloom period: they overwinter at depth in dormancy and are able to fuel their gonad maturation from lipid reserves, and their offspring make the most of the brief productive season (Hagen and Auel, 2001). However, years with very early or very late ice retreat can lead to poor population development of these species (Quetin and Ross, 2003; Ward et al., 2006; Leu et al., 2011). Optimal conditions are reached when peak times of food demand and food availability are tightly matched (Quetin and Ross, 2003; Søreide et al., 2010). A change towards earlier sea ice retreat has been suggested to cause severe mismatches (Søreide et al., 2010). Whether this has already impacted the populations of polar grazers is largely unknown, however, due to the paucity of adequate baseline data that allow us to distinguish interannual variability from long-term trends (Wassmann et al., 2011).

An exception is Antarctic krill that have been sampled extensively over the last 90 years due to their central role in Antarctic food webs and their commercial interest (Smetacek and Nicol, 2005). The main habitat of Antarctic krill is the south-west Atlantic sector of the Southern Ocean (Atkinson et al., 2008), which largely overlaps with areas of negative trends in sea ice concentrations (western Antarctic Peninsula, north-west Weddell Sea) (Stammerjohn and Maksym, 2017). A long-term data set shows that krill stocks in this region have declined significantly (Atkinson et al., 2014), with consequences for populations of krill predators such as penguins and seals (Fraser and Hoffmann, 2003; Forcada and Hoff- 
mann, 2014). Concurrent expansion and operational changes in Antarctic krill fisheries (Kawaguchi et al., 2009) make the krill decline a significant issue of Southern Ocean ecosystem management (Flores et al., 2012b). However, the key mechanism linking krill and sea ice remains elusive (Meyer et al., 2017). Some studies stress the crucial role of sea ice for overwinter survival of krill larvae by providing food and shelter (Meyer et al., 2009; Kohlbach et al., 2017), while others point to sea ice as an important habitat for juvenile and adult krill during spring and summer (Marschall, 1988; Flores et al., 2012a) or emphasise indirect effects of seasonal ice cover due to its control on summer phytoplankton productivity and therefore krill recruitment (Quetin and Ross, 2003; Saba et al., 2014).

To resolve some of this uncertainty it is essential to quantify the relative importance of sea-ice-derived, seaice-conditioned and non-sea-ice-associated primary production for krill nutrition and to relate dietary differences to the performance of krill in terms of growth, recruitment and accumulation of body reserves. However, ice-algaeproduced carbon has rarely been traced through Southern Ocean food webs (Goutte et al., 2013; Jia et al., 2016; Kohlbach et al., 2017), as distinguishing it unambiguously from phytoplankton-produced carbon is difficult. Here we tackle this challenge by measuring two highly branched isoprenoid (HBI) biomarkers, which are metabolites of certain diatom species and established proxies for palaeo sea ice reconstructions (Belt and Müller, 2013). Around Antarctica, mixtures of a di-unsaturated HBI (referred to as diene II in previous studies; see Fig. S1 in the Supplement) and a tri-unsaturated HBI (referred to as triene III in previous studies, thereafter HBI III; Fig. S1) have repeatedly been found in sediment cores, water column samples and Antarctic predators (Massé et al., 2011; Collins et al., 2013; Goutte et al., 2013, 2014a, b; Smik et al., 2016). The samples were obtained from the Atlantic, Indian and Pacific sectors of the Southern Ocean, suggesting a widespread occurrence of these biomarkers. However, only diene II has been identified in sea ice samples, and its enrichment in ${ }^{13} \mathrm{C}\left(\delta^{13} \mathrm{C}=-5.7\right.$ to $-17.8 \%$ ) is in line with a reduced availability of dissolved inorganic carbon within the semi-enclosed sea ice matrix (Massé et al., 2011). This has led to the name "Ice Proxy for the Southern Ocean with 25 carbon atoms" (IPSO 25$)$, with the sympagic diatom Berkeleya adeliensis being recently identified as one of the source species (Belt et al., 2016). In contrast, HBI III is produced by certain pelagic diatom species, e.g. Rhizosolenia spp. (Belt et al., 2017), and its significantly lighter stable isotopic signature $\left(\delta^{13} \mathrm{C}=-35.0\right.$ to $-41.6 \%$ ) indicates a replete carbon pool typical for open waters (Massé et al., 2011). Previous water column and sediment studies have shown relative enhancements in HBI III within the MIZ in the Arctic and Antarctic (Collins et al., 2013; Belt et al., 2015; Smik et al., 2016; Ribeiro et al., 2017), even when other productivity signatures were less revealing, possibly reflecting a preferred habitat for the HBI
III-producing species within this setting (Belt et al., 2015). As such, measurements of these two HBIs provide an opportunity to distinguish between direct and indirect effects of sea ice: $\mathrm{IPSO}_{25}$ indicates ice-algae-produced carbon, while HBI III indicates phytoplankton-produced carbon in waters conditioned by sea ice (i.e. the MIZ). Importantly, both $\mathrm{IPSO}_{25}$ and HBI III have been identified in body tissues of seabirds, seals and fish, which confirms their transfer across Antarctic food webs and supports their use as trophic markers (Goutte et al., 2013, 2014a, b). However, detailed interpretation of these biomarkers still lacks basic knowledge about (1) the oceanographic conditions (e.g. sea ice history, stratification, mixed layer depth, chl $a$ concentration) that favour the abundance of $\mathrm{IPSO}_{25}$ and HBI III-producing diatoms; (2) the subsequent uptake and turnover of IPSO $_{25}$ and HBI III by Antarctic grazers; and (3) the link between the ingested carbon source and the performance of the grazers.

In this study, we contribute to the development of the HBIbased approach by analysing Antarctic krill and suspended material during seasonal sea ice retreat in the Scotia Sea (Atlantic sector of the Southern Ocean) in January-February 2003. The suitability of different feeding grounds (MIZ, permanently ice-free Scotia Sea, South Georgia) for pelagic grazers was established based on the mass-length ratio, size of digestive gland and growth rate of krill, and recruitment of the biomass-dominant calanoid copepods Calanoides acutus and Calanus propinquus.

\section{Methods}

\subsection{Satellite-derived chlorophyll $a$ data}

To gain an overview of phytoplankton development during the year of our field season (2002/2003) and for comparison with other years, we used satellite-derived chl $a$ data. These provide large-scale, quasi-synoptic coverage of chl $a$ concentrations in surface waters but have the caveat that deep chl $a$ maxima are not detected. Data were obtained from ocean colour radiometry (MODIS, $9 \mathrm{~km}$ standard product, 8-day composites, 6 September-30 March 2002-2015). The Scotia Sea $\left(55-63^{\circ} \mathrm{S}, 25-60^{\circ} \mathrm{W}\right)$ and South Georgia region $\left(52-55^{\circ} \mathrm{S}, 32-42^{\circ} \mathrm{W}\right)$ were divided into subareas of $1^{\circ}$ lat by $2.5^{\circ}$ long. For each of these subareas the monthly and seasonal mean chl $a$ concentration and bloom duration (number of weeks with chl $a 0.5 \mathrm{mg} \mathrm{m}^{-3}$ ) were determined for the 2002/2003 season and compared with the 13-year average, 2002-2015. Results were displayed using Ocean Data View (ODV) software (Schlitzer, 2017).

\subsection{Sea ice cover}

For the 2002/2003 season, monthly sea ice edges were calculated using sea ice concentrations from Nimbus-7 SMMR and DMSP SSM/I-SSMIS passive microwave data. Monthly composites were calculated using the median of the daily 
grids for each month. These were then contoured at $15 \%$ to extract a line indicating average position of the sea ice edge for each month. Timelines of sea ice cover at each of our sampling stations were established within a $50 \mathrm{~km}$ radius. Using these zones, we extracted an average value of sea ice concentration on a daily basis. The input data were derived from Microwave Scanning Radiometer for the Earth Observation System (AMSR-E) aboard the NASA's Aqua satellite and the Defense Meteorological Satellite Program SSM/I, which is at a higher spatial resolution of $6.25 \mathrm{~km}$. Further details are given in Cavalieri et al. (1996) and Spreen et al. (2008).

\subsection{Station sampling of oceanographic parameters}

Shipboard data were collected from the research vessel RRS James Clark Ross cruise JR82 between 9 January and 16 February 2003. Fifty-five hydrographic stations were positioned at $110 \mathrm{~km}$ intervals along eight transects across the Scotia Sea, commencing north of Elephant Island and traversing eastward. A further six stations were located to the north-west of South Georgia (Fig. 1). At each station, vertical profiles of conductivity-temperature-depth (CTD) and blue light-stimulated chlorophyll fluorescence were collected with a SeaBird 911+CTD and attached Aqua-Tracka Mk III fluorometer (Chelsea Instruments) (Korb et al., 2005). Mixed layer depths were calculated as the depth where the density difference $(\Delta \sigma)$ relative to the surface water is $0.05 \mathrm{~kg} \mathrm{~m}^{-3}$ (Venables et al., 2013). Size-fractionated chl $a$ was measured from water samples collected at $20 \mathrm{~m}$ depth. Samples were filtered sequentially onto a series of 12,2 and $0.2 \mu \mathrm{m}$ polycarbonate membrane filters $(47 \mathrm{~mm}$ diameter) and analysed for chl $a$ after extraction in $90 \%$ acetone (Korb et al., 2005).

\subsection{Sampling of suspended matter, krill and faecal pellets}

Suspended matter was sampled from the ship's non-toxic seawater supply located $\sim 6 \mathrm{~m}$ below the sea surface. Seawater samples $(3 \mathrm{~L})$ were filtered onto pre-ashed $\mathrm{GF} / \mathrm{F}$ filters and stored at $-80^{\circ} \mathrm{C}$ until analysis. Krill swarms were identified in the vicinity of each station using a Simrad EK60 echosounder and sampled with a rectangular midwater trawl (RMT 8). The RMT was equipped with two nets that were opened and closed remotely from the ship, allowing short duration hauls targeted on specific krill schools in the upper $50 \mathrm{~m}$ of the water column. One subsample of the freshly caught krill was immediately frozen at $-80^{\circ} \mathrm{C}$ for subsequent analysis of HBIs. Another subsample of krill was kept alive to allow for defecation. These krill were placed into buckets filled with surface water and pellets were collected as soon as visible on the bottom of the buckets. The pellets were transferred into $1 \mathrm{~mL}$ Eppendorf tubes and rinsed repeatedly with GF/F-filtered seawater with a final brief rinse in deionised water. The supernatant water was removed and vials were stored at $-80^{\circ} \mathrm{C}$.

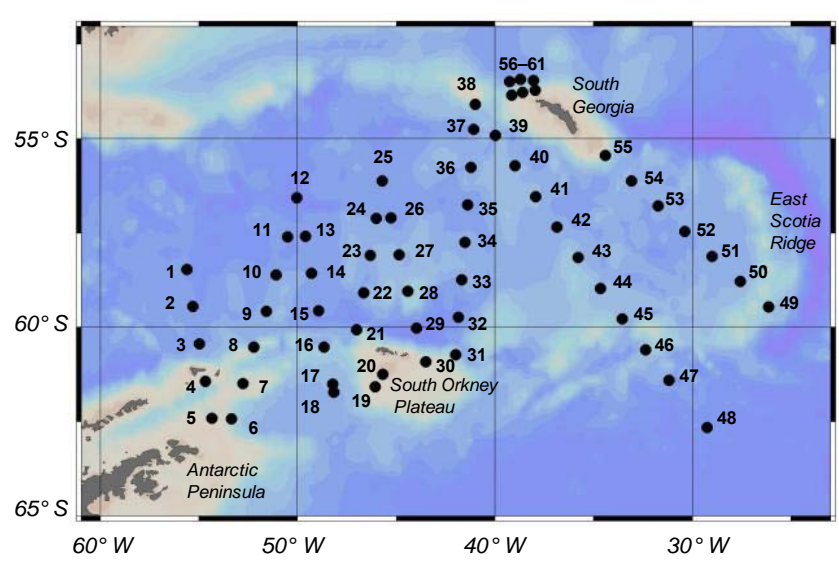

Figure 1. Scotia Sea and South Georgia: sampling locations during austral summer 2003. The date of sampling progressed from 9 January (station 1$)$ to 16 February (station 61$)$. Shelf areas $(\leq 1000 \mathrm{~m})$ are presented in light brown colour.

\subsection{Krill dissections}

In the laboratory, krill body length was measured from the anterior lateral edge of the carapace to the posterior edge of the sixth abdominal segment (standard 3 body length). Three to 15 individuals of the same body length $( \pm 1 \mathrm{~mm})$ were selected for HBI analysis. Standard 3 lengths of selected krill ranged from 16 to $42 \mathrm{~mm}$. If available, up to six different size classes, each differing by at least $2 \mathrm{~mm}$, were analysed per station. Then, krill were dissected into stomach content, gut, digestive gland, third abdominal segment (muscle) and remaining body. A pooled sample of each of these components was placed in a pre-weighed vial, freeze-dried for $24 \mathrm{~h}$ and re-weighed on a Sartorius microbalance. The mass of the digestive gland was related to the total body mass.

\subsection{HBI extraction and analysis}

HBIs were extracted and analysed as described previously for filtered seawater samples and zooplankton tissue (Brown and Belt, 2012; Smik et al., 2016; Belt et al., 2016). In brief, freeze-dried faecal pellets and krill body fractions were ground using a pestle and mortar. Following addition of an internal standard (9-octyl-8-heptadecene $(10 \mu \mathrm{L}$; $\left.2 \mu \mathrm{g} \mathrm{m}^{-1}\right)$ ) to facilitate HBI quantification, samples were saponified with $5 \% \mathrm{KOH}$ (filters) or $20 \% \mathrm{KOH}$ (krill tissue) $\left(70{ }^{\circ} \mathrm{C} ; 60 \mathrm{~min}\right)$. Thereafter, non-saponifiable lipids were extracted with hexane $(3 \times 1 \mathrm{~mL})$ and purified by open column chromatography $\left(\mathrm{SiO}_{2}\right)$. HBIs were eluted using hexane (five column volumes) before being dried $\left(\mathrm{N}_{2}\right.$ stream, $25^{\circ} \mathrm{C}$ ). The analysis of partially purified non-polar lipids containing $\mathrm{IPSO}_{25}$ and $\mathrm{HBI}$ III was carried out using an Agilent 7890A gas chromatograph (GC), coupled to an Agilent 5975 mass selective detector (mass spectrometry, MS), fitted with an Agilent HP-5ms column with auto-splitless injection 
and helium carrier gas. Identification of individual lipids was achieved by comparison of their retention index and mass spectrum with those obtained from purified standards. Quantification of $\mathrm{IPSO}_{25}$ and HBI III was achieved by integrating individual ion (IPSO $25: m / z$ 348.3; HBI III: $m / z$ 346.3) responses in selected-ion monitoring mode and normalising these to the corresponding peak area of the internal standard and an instrumental response factor obtained from purified standards (Belt et al., 2012). The GC-MS-derived masses of both HBIs were converted to water column concentrations using the volume of filtered seawater and to concentrations in krill body fractions using the mass of the sample extracted. For simplicity in representing biomarker ratios, we use the terms I and $\mathrm{H}$ for $\mathrm{IPSO}_{25}$ and $\mathrm{HBI}$ III, respectively. Thus, the proportion of $\mathrm{IPSO}_{25}$ to the combined concentration of $\mathrm{IPSO}_{25}$ and HBI III is given by $\mathrm{I} /(\mathrm{I}+\mathrm{H})$.

\subsection{Stable isotope determination}

The stable carbon isotopic compositions $\left(\delta^{13} \mathrm{C}\right)$ of $\mathrm{IPSO}_{25}$ and HBI III were determined in krill from four sampling locations near the retreating ice edge (stations 5, 17, 31 and 47). Analysis was carried out by gas chromatography-isotope ratio mass spectrometry (GC-IRMS), using an IsoPrime100 IRMS with GC5 interface and Agilent 7890B GC installed with an Agilent HP-5MS column $(30 \mathrm{~m} \times 0.2 \mathrm{mmm}$ I.D., film thickness $0.25 \mu \mathrm{m})$. Samples in ca. $10-150 \mu \mathrm{L}$ hexane were injected in splitless mode with the following inlet conditions: temperature of $250^{\circ} \mathrm{C}$, purge flow of $25 \mathrm{~mL} \mathrm{~min}^{-1}$ and purge time of $0.75 \mathrm{~min}$. GC carrier gas $(\mathrm{He})$ flow rate was $1 \mathrm{~mL} \mathrm{~min}{ }^{-1}$. The oven program was as follows: $1 \mathrm{~min}$ hold at $50^{\circ} \mathrm{C}$, ramp to $310^{\circ} \mathrm{C}$ at $10^{\circ} \mathrm{C} \mathrm{min}^{-1}$, then $13 \mathrm{~min}$ hold. The combustion furnace consisted of a $0.7 \mathrm{~mm}$ I.D. quartz tube packed with $\mathrm{CuO}$ pellets and held at $850^{\circ} \mathrm{C}$. GC-IRMS data were calibrated using the certified Indiana alkane standard mix A5 (Indiana University, Bloomington, IN, USA) and all results reported in delta notation $\left(\delta^{13} \mathrm{C}\right)$ relative to VPDB. IPSO 25 and HBI III were identified in GCIRMS chromatograms by retention time comparison with corresponding GC-MS analyses. IonOS software (Elementar UK Ltd) was used to process GC-IRMS data; "peak mapping" functionality was used to designate specific compound identifications across multiple injections. The A5 alkane mix was analysed in at least duplicate, and calibrations were constructed from at least three interspersed replicate measurements of the A5 mix. Reproducibility of all individual alkanes was always $\leq 0.35 \%$. Root mean square error (RMSE) of each of the calibrations was usually $\leq 0.25 \%$, with an overall RMSE for all calibrations combined of $\leq 0.21 \%$, reflecting both the reliability of each calibration and the longterm stability of the system (analyses were undertaken over a 3 -week period in total). Samples containing IPSO ${ }_{25}$ and HBI III were run in triplicate; precisions for both compounds were $\leq 0.27$ (see Table 1 ).

\subsection{Copepod abundance and stage composition}

Copepods were collected at each station with a motioncompensating Bongo net of $200 \mu \mathrm{m}$ mesh size. The net was deployed to $400 \mathrm{~m}$ and hauled vertically back to the surface. The content of the net was preserved in $10 \%(v: v)$ formalin in seawater. In the laboratory, samples were divided into appropriate aliquots with a Folsom plankton splitter and examined under a binocular microscope. Calanoides acutus and Calanus propinquus were identified to their copepodite stages (CI-V: juveniles; CVI: adults). The mean age of the population was calculated as the sum of the products of each stage number and its abundance, divided by the total abundance.

\section{Results}

\subsection{Development of the Scotia Sea phytoplankton bloom in 2002/2003}

In October 2002, elevated chl a concentrations $\left(>0.5 \mathrm{mg} \mathrm{m}^{-3}\right)$ were found north of South Georgia $\left(\sim 53^{\circ} \mathrm{S}\right)$, and 1 month later in the north-eastern Scotia Sea $\left(\sim 56^{\circ}\right.$ S; Fig. 2a). With the rapid retreat of sea ice in December 2002, the bloom in the east extended south and reached the northern Weddell Sea in January $2003\left(\sim 62^{\circ} S\right.$; Fig. 2b). In February 2003, chl $a$ concentrations remained high in the eastern Scotia Sea and at South Georgia, but started to decline in March (Fig. 2c). In the western and central Scotia Sea, chl a concentrations remained low throughout the summer, apart from slightly enhanced values across the South Orkney Plateau in January 2003. Compared to the 13-year average (2002-2015), there was a negative anomaly in phytoplankton abundance in the central Scotia Sea in 2002/2003, but a surplus in the east (Fig. 2d, e). At the East Scotia Ridge, mean annual chl $a$ concentrations were up to $0.7 \mathrm{mg} \mathrm{m}^{-3}$ higher and the bloom lasted up to 16 weeks longer in 2002/2003 compared to the 2002-2015 average (Fig. 2e).

\subsection{Spatial distribution of oceanographic data and HBIs}

During maximum sea ice extent the previous winter, about two-thirds of our sampling stations were ice covered (Fig. 3a). Thirty days before each station was occupied, the southern Scotia Sea was still ice covered by $50-75 \%$ concentration (Fig. 3b), but values had dropped to $<6 \%$ at the time of sampling. Surface temperatures ranged from $-1.2^{\circ} \mathrm{C}$ at stations near the ice edge to $4.5^{\circ} \mathrm{C}$ at South Georgia (Fig. 3c). Surface salinity was likewise lowest near the retreating ice edge and highest within the Southern Antarctic Circumpolar Current Front (range: 33.1-34.4; Fig. 3d). Stations of the Scotia Sea that had been ice covered showed a stronger vertical density gradient and shallower mixed layer than northerly 

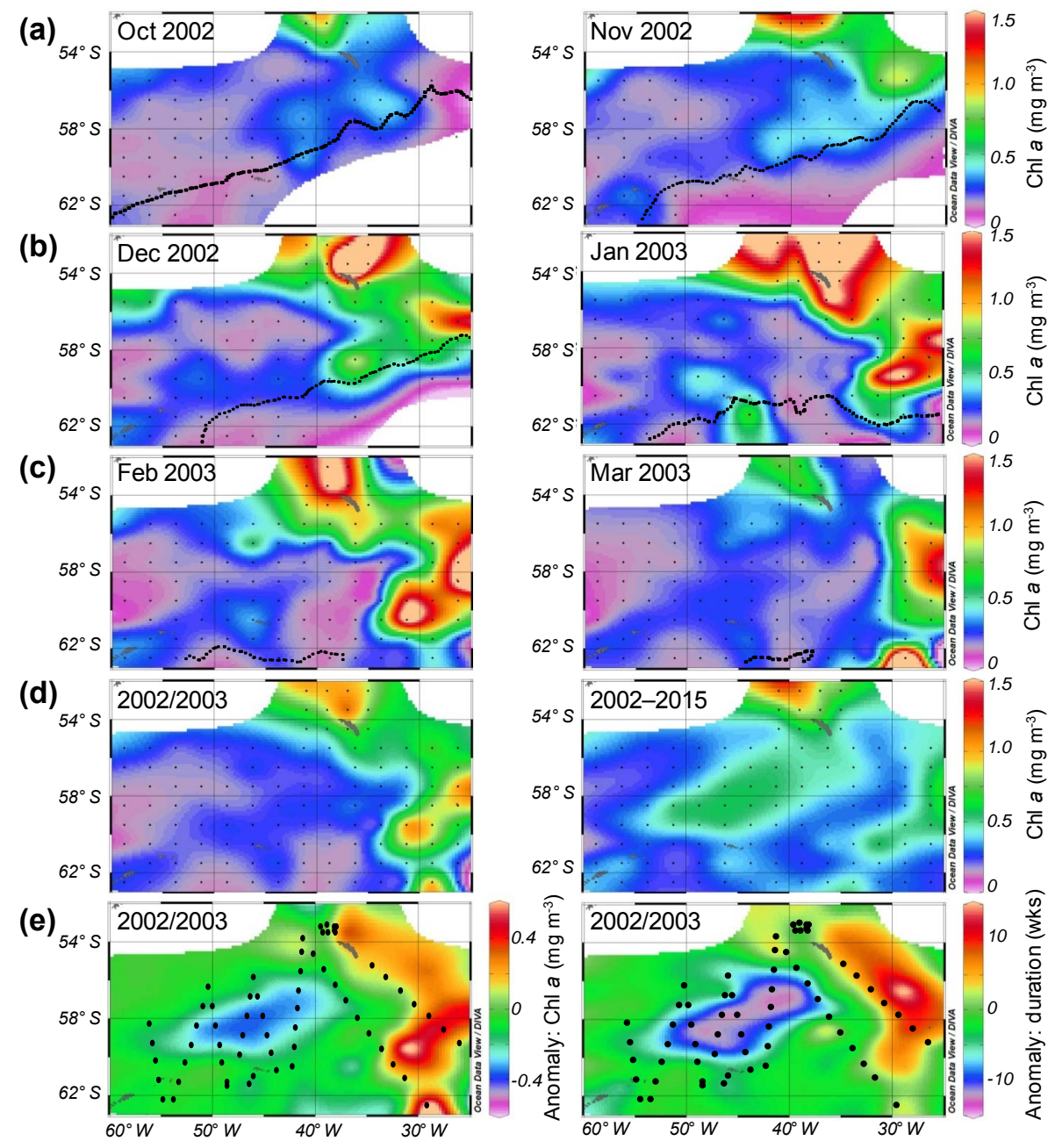

Figure 2. Phytoplankton bloom development in the Scotia Sea. Monthly mean chl $a$ concentrations in 2002/2003; (a) the early season, (b) the mid-season, and (c) the late season. (d) Seasonal mean chl $a$ concentrations (September-March) in 2002/2003 and over the 13-year average of 2002-2015. (e) Anomaly in seasonal mean chl $a$ concentration (left) and bloom duration (right) for 2002/2003 compared to the 13-year average of 2002-2015. Chl $a$ concentrations were derived from ocean colour radiometry (MODIS, 8-day composites, September-March). A bloom was defined as $>0.5 \mathrm{mg} \mathrm{Chl} a \mathrm{~m}^{-3}$. The dashed line represents the mean position of the $15 \%$ ice edge during each of the months. In (e), the position of our sampling stations is given.

stations that remained ice-free (Fig. 3e, f). Highest surface chl $a$ concentrations in the eastern Scotia Sea and near South Georgia coincided with the dominance of large phytoplankton size classes (Fig. 3g, h).

Out of the 61 stations where suspended matter was analysed for HBIs, 6 contained IPSO 25 and 51 HBI III (Fig. 4a, b). Stations where $\mathrm{IPSO}_{25}$ occurred in suspended matter were all located near the ice edge (stations 6, 18, 19, 20, 31,48 ), while stations with elevated HBI III concentrations were found near the ice edge (stations 45, 46, 49-53) and further north (stations 12, 25, 26, 37, 40). At stations where both HBIs co-occurred, $\mathrm{IPSO}_{25}$ concentrations usually exceeded those of HBI III (mean I / ( $+\mathrm{H}): 0.6 \pm 0.3, n=6$; Fig. 4c). In addition to suspended matter, krill from 47 stations were analysed for HBIs. IPSO 25 was present in krill from 21 stations, while HBI III was found in krill from all 47 stations (Fig. 4d, e). The spatial distribution of $\mathrm{IPSO}_{25}$ in krill matched that found in suspended matter, with highest concentrations near the ice edge. However, $\mathrm{IPSO}_{25}$ was also detected in krill from stations further north, even though it was not identified in suspended matter from the upper mixed layer. Highest HBI III concentrations in krill were observed in the central Scotia Sea (stations 13, 14, 22) and in the east (stations $47,52,54$ ), which only partly overlaps with locations of highest HBI III concentrations in suspended matter. However, as for suspended matter, highest $\mathrm{I} /(\mathrm{I}+\mathrm{H})$ ratios in krill occurred near the ice edge in the western and central Scotia Sea (mean I ( $\mathrm{I}+\mathrm{H}): 0.3 \pm 0.2, n=21$; Fig. 4f). 
(a)

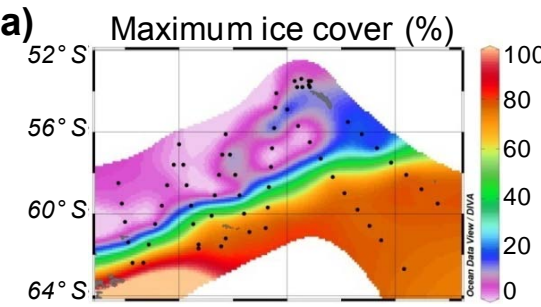

(c)

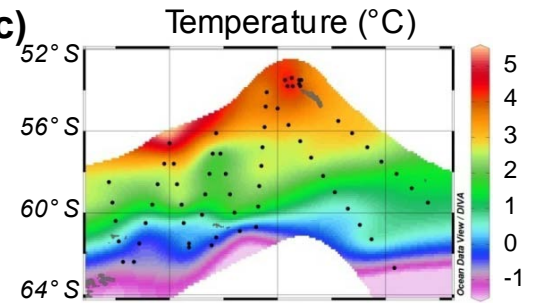

(e)
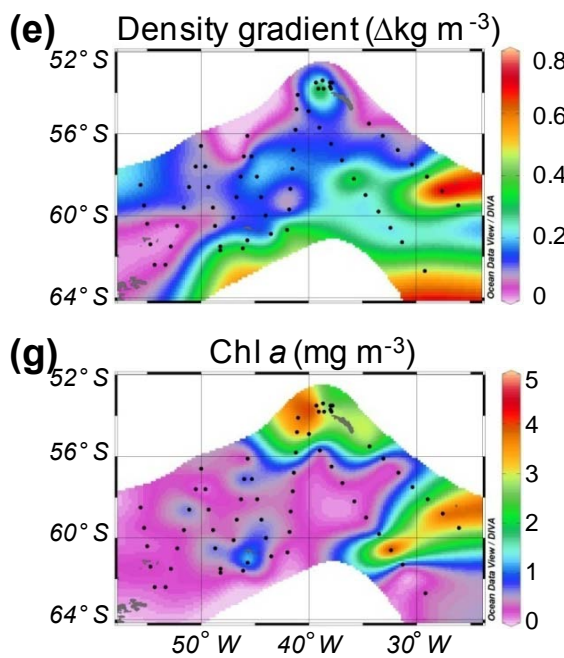

(b)

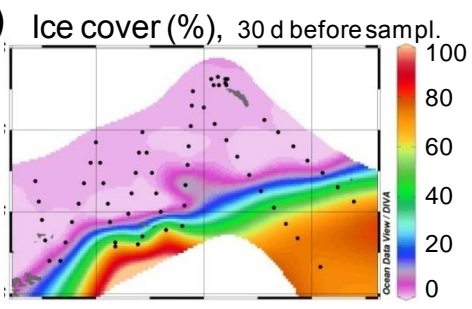

(d)

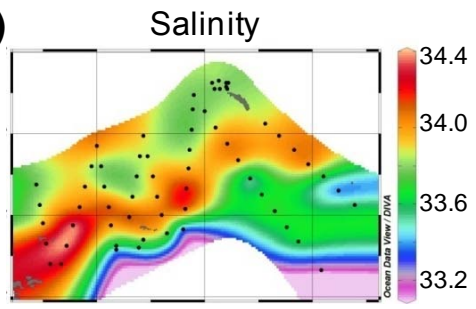

(f)

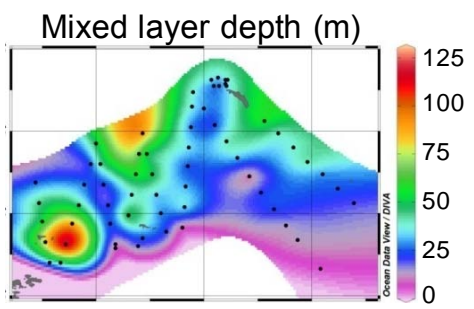

(h)

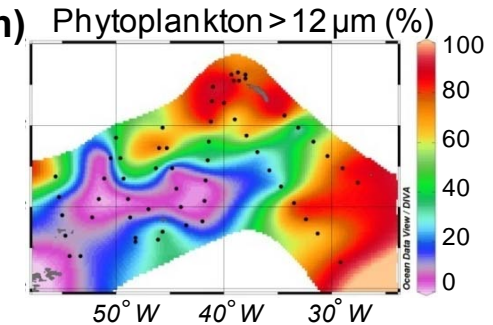

Figure 3. Oceanographic data: (a) maximum ice cover during the previous winter (August-September-October 2002). (b) Ice cover 30 days before each station was occupied. (c) Surface temperature. (d) Surface salinity. (e) Maximum density gradient per $10 \mathrm{~m}$ water column. (f) Mixed layer depth. (g) Total chlorophyll $a(\mathrm{chl} a)$ concentration of cells $>0.2 \mu \mathrm{m}$. (h) Proportion of large phytoplankton (>12 $\mu \mathrm{m})$ based on size-fractionated chl $a$ measurements (\% of total chl $a$ ).

Table 1. Euphausia superba: carbon isotopic signature $\left(\delta^{13} \mathrm{C}\right)$ of $\mathrm{IPSO}_{25}$ and $\mathrm{HBI}$ III extracted from $\sim 30$ pooled, whole krill (mean $\pm \mathrm{SD}$, $n=3$ ) at four sampling locations near the retreating ice edge. LOD is below limit of detection.

\begin{tabular}{rrrrrr}
\hline & Station 5 & Station 17 & Station 31 & Station 47 & Mean \\
\hline$\delta^{13} \mathrm{C}-\mathrm{IPSO}$ \\
$25(\% \circ)$ & $-15.75 \pm 0.15$ & $-12.63 \pm 0.15$ & $-9.21 \pm 0.02$ & $<$ LOD & $-12.53 \pm 3.27$ \\
$\delta^{13} \mathrm{C}-\mathrm{HBI}$ III (\%o) & $-42.54 \pm 0.27$ & $<$ LOD & $-39.09 \pm 0.16$ & $-45.05 \pm 0.07$ & $-42.23 \pm 2.44$ \\
\hline
\end{tabular}

\subsection{The habitat of IPSO ${ }_{25}$ vs. HBI III-producing diatoms}

The carbon isotopic signature $\left(\delta^{13} \mathrm{C}\right)$ of $\mathrm{IPSO}_{25}$ extracted from krill sampled at three different locations near the ice edge (stations $5,17,31$ ), ranged from -9.2 to $-15.7 \%$ o (mean: $-12.5 \pm 3.2 \%$; Table 1 ). Such high $\delta^{13} \mathrm{C}$ values are indicative of a reduced availability of dissolved inorganic carbon as common in the semi-enclosed sea ice matrix (Wang et al., 2014). In line with a sea ice origin of $\mathrm{IPSO}_{25}$, stations with high $\mathrm{IPSO}_{25}$ concentrations in suspended matter (stations $18,19,20,31$ ) were characterised by recent sea ice retreat, sub-zero surface temperatures, low surface salinity and relatively low chl $a$ concentrations (Fig. 5). In contrast, HBI III extracted from the same krill showed much lower $\delta^{13} \mathrm{C}$ values (-39.1 to $-42.5 \%$; Table 1$)$, suggesting a production in open waters where the dissolved inorganic carbon 


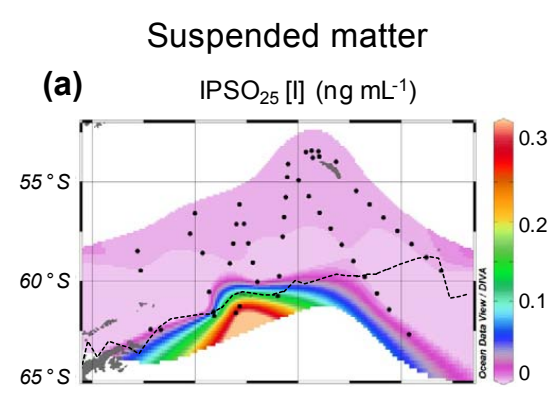

(b)
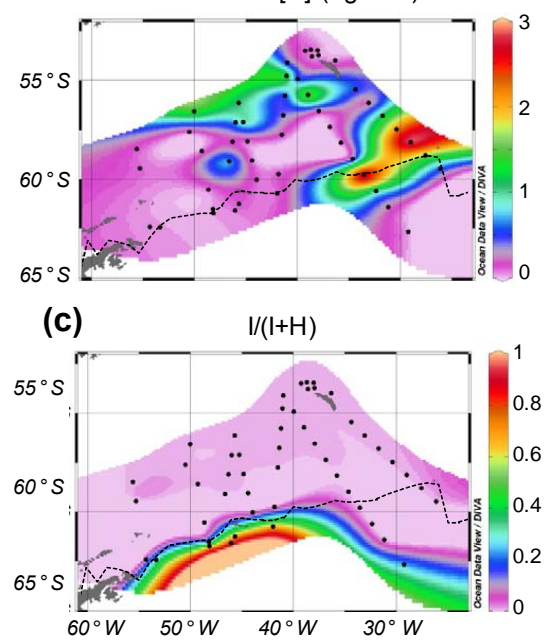

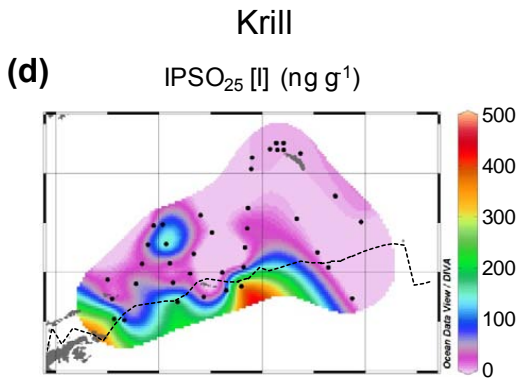

(e)

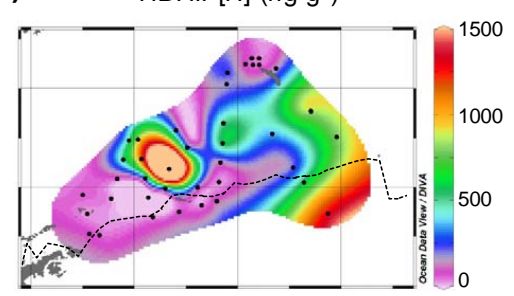

(f)

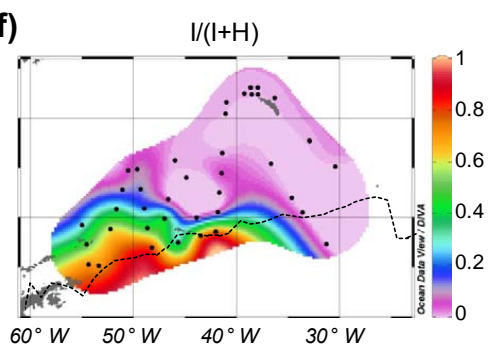

Figure 4. Highly branched isoprenoid (HBI) concentrations in suspended matter from surface waters (left) and whole krill (right): (a, d) $\mathrm{IPSO}_{25}$ concentrations; (b, e) HBI III concentrations; (c, f) IPSO $_{25}$ vs. HBI III ratios. The dashed line represents the mean position of the $15 \%$ ice edge during January.

pool is replete. Stations with high HBI III concentrations in suspended matter (stations $45,50,51,52$ ) had been ice-free for $\sim 1$ month at the time of sampling. Here, higher temperatures, higher surface salinity and elevated chl $a$ concentrations indicate a progression of upper water column processes since the ice melt (Fig. 5).

In the south-eastern Scotia Sea, there was a large area where high HBI III concentrations coincided with elevated chl $a$ concentrations and high proportions of large phytoplankton (Fig. 3g, h, Fig. 4b). Oceanographically, this area was characterised by shallow upper mixed layers and a strong vertical gradient in salinity (Fig. 3c-f, Fig. S2). A comparison of the stations' history of ice cover shows that the vertical density gradient was driven by ice melt. Across the Scotia Sea, there was a highly significant linear relationship between density and salinity gradients, with strongest density gradients at stations that had $>30 \%$ ice cover 1 month before sampling (Fig. 6). This supports salinity as the main driver of seawater density and therefore stratification at polar temperatures (Smith and Nelson, 1986).

\subsection{IPSO $_{25}$ and HBI III concentrations in krill - the role of body fraction and body size}

The analysis of krill body fractions shows that not all of the ingested $\mathrm{IPSO}_{25}$ and HBI III was absorbed into body tissue, but part remained in the intestine and was then egested via their faecal pellets (Table 2). Thus, $\mathrm{IPSO}_{25}$ and HBI III concentrations were highest in the stomach content, followed by the digestive gland and gut content, and lowest in muscle tissue.

The I / $(\mathrm{I}+\mathrm{H})$ ratio within the various krill body fractions can reveal recent and past feeding history (Fig. 7a-d). The $\mathrm{I} /(\mathrm{I}+\mathrm{H})$ ratios in krill stomach content were highest at stations closest to the ice edge in the western and central Scotia Sea, indicating that here the krill diet was mainly based on sea ice diatoms. At four stations near the ice edge and up to $\sim 200 \mathrm{~km}$ further north, krill had moderate I/ $(\mathrm{I}+\mathrm{H})$ ratios in their stomach content, suggesting a mixed diet of ice-derived diatoms and open water diatoms. Low I / $(\mathrm{I}+\mathrm{H})$ ratios in krill stomachs, but higher ratios in their muscle and rest of the body were found at 11 stations $\sim 200-600 \mathrm{~km}$ north of the ice edge, suggesting that krill had been feeding on ice diatoms in the past but had switched to open water 

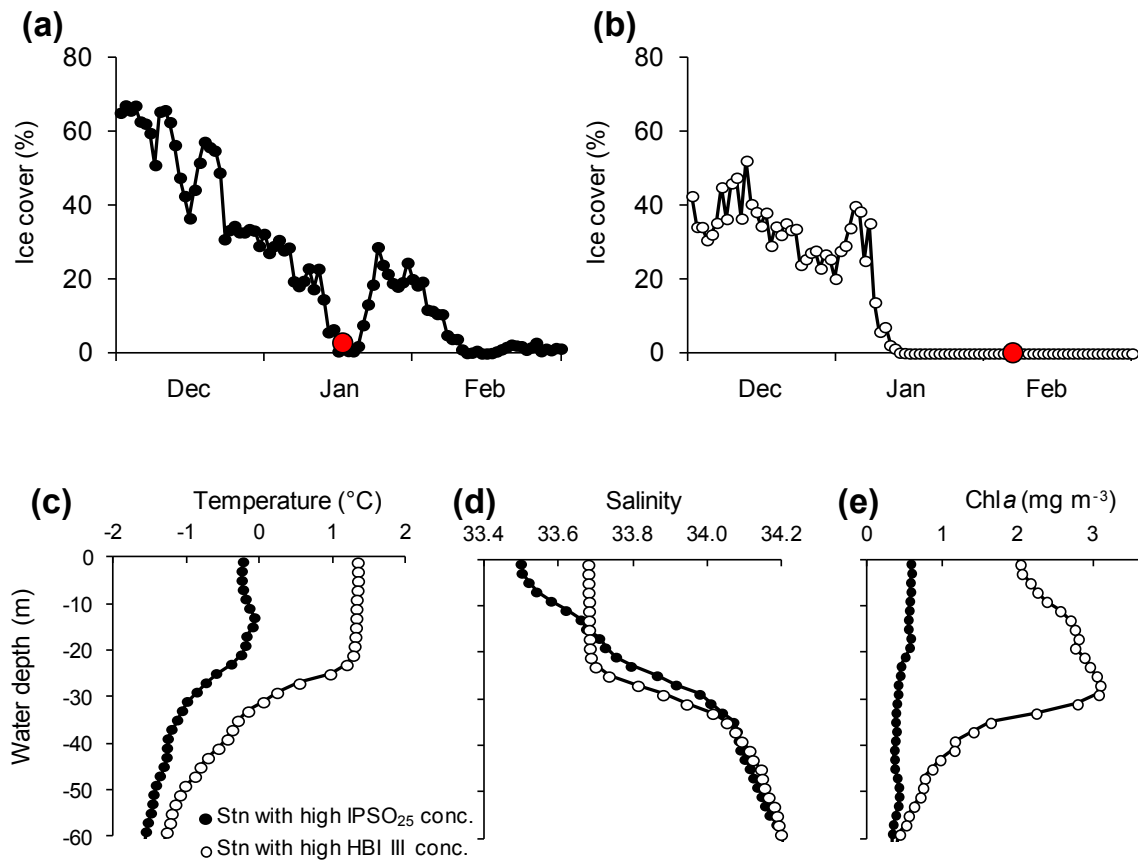

(d) Salinity

(e) $\quad \operatorname{Chla}\left(\mathrm{mg} \mathrm{m}^{-3}\right)$
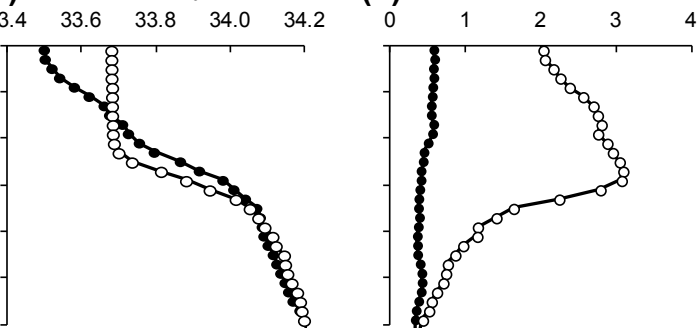

Figure 5. Oceanographic differences between stations with high $\mathrm{IPSO}_{25}$ vs. high HBI III concentrations in suspended matter. (a) Timeline of sea ice cover at stations with high $\mathrm{IPSO}_{25}$ concentrations (mean of stations 18, 19, 20, 31). The red dot indicates the time of sampling. (b) Timeline of sea ice cover at stations with high HBI III concentrations (mean of stations 45, 50, 51, 52). (c) Vertical profiles of temperature, (d) salinity and (e) chlorophyll $a$.

Table 2. Euphausia superba: concentrations of $\mathrm{IPSO}_{25}$ and $\mathrm{HBI}$ III in different body fractions. Average stomach values are used as baseline for comparisons across body fractions, "Ratio (stomach $/ X$ )". $X$ is the digestive gland, gut, muscle, rest or whole krill. The $\mathrm{I} /(\mathrm{I}+\mathrm{H})$ ratio was calculated as the ratio of means for those stations where both $\mathrm{IPSO}_{25}$ and $\mathrm{HBI}$ III had been detected in at least one of the body fractions. $r$ is the range.

\begin{tabular}{|c|c|c|c|c|c|c|c|}
\hline & \multicolumn{3}{|c|}{$\mathrm{IPSO}_{25}$} & \multicolumn{3}{|c|}{ HBI III } & \multirow{2}{*}{$\begin{array}{r}\mathrm{I} /(\mathrm{I}+\mathrm{H}) \\
\text { Ratio of } \\
\text { means }\end{array}$} \\
\hline & $\begin{array}{r}\text { Mean }( \pm \mathrm{SD}) \\
\left(\mathrm{ng} \mathrm{g}^{-1}\right)\end{array}$ & $\begin{array}{l}\text { Maximum } \\
\left(\mathrm{ng} \mathrm{g}^{-1}\right)\end{array}$ & $\begin{array}{r}\text { Ratio } \\
(\text { stomach } / X)\end{array}$ & $\begin{array}{r}\text { Mean }( \pm \mathrm{SD}) \\
\left(\mathrm{ng} \mathrm{g}^{-1}\right)\end{array}$ & $\begin{array}{r}\text { Maximum } \\
\left(\operatorname{ng~g}^{-1}\right)\end{array}$ & $\begin{array}{r}\text { Ratio } \\
(\text { stomach } / X)\end{array}$ & \\
\hline Stomach & $2875 \pm 5277$ & 14337 & & $14358 \pm 18844$ & 58902 & & $r: 0.00-0.95$ \\
\hline Digestive gland & $958 \pm 1609$ & 4523 & 3 & $5018 \pm 6043$ & 19686 & 3 & $r: 0.00-0.92$ \\
\hline Gut & $812 \pm 1414$ & 3601 & 3.5 & $52027 \pm 167732$ & 584461 & 0.3 & $r: 0.00-0.91$ \\
\hline Muscle & $51 \pm 46$ & 125 & 56 & $245 \pm 238$ & 861 & 59 & $r: 0.01-0.51$ \\
\hline Rest & $188 \pm 160$ & 387 & 15 & $804 \pm 731$ & 2340 & 18 & $r: 0.00-0.62$ \\
\hline Whole krill & $219 \pm 222$ & 618 & 13 & $1393 \pm 1638$ & 3221 & 10 & $r: 0.00-0.73$ \\
\hline Pellets & $1549 \pm 379$ & 1973 & & $1263 \pm 410$ & 4419 & & \\
\hline
\end{tabular}

Analysed stations $\left(\mathrm{IPSO}_{25}\right.$ ): stations 5, 10, 13, 14, 17, 22, 31, 34, 54 Analysed stations (HBI III): stations 5, 10, 13, 14, 17, 22, 31, 34, 47, 54, 60 Analysed stations

$(\mathrm{I} /(\mathrm{I}+\mathrm{H})$ ): stations 5, 10, 13, 14, 17, 22, 31, 34, 54 Analysed stations, pellets (IPSO 25$)$ : stations 21, 32 Analysed stations, pellets (HBI III): stations 9, 10, 15, 21, 31, 32,

$34,42,45,47,52,54,60,61$ 


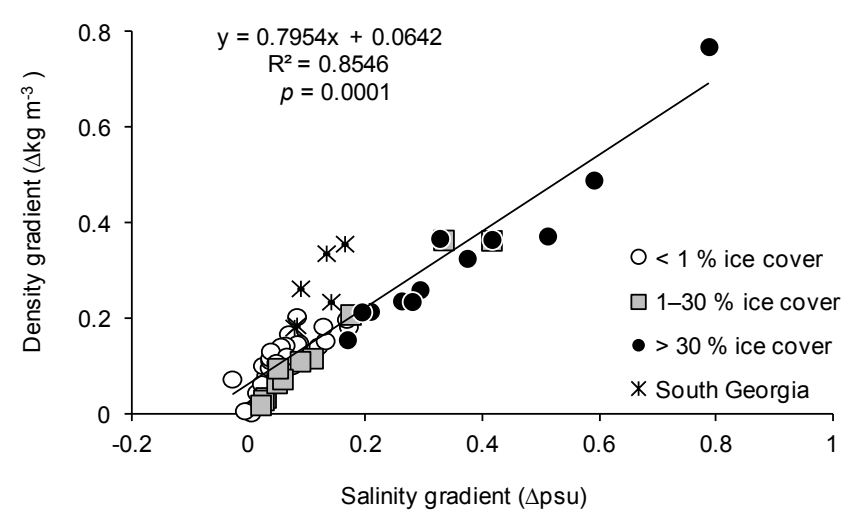

Figure 6. The role of seasonal ice melt for water column stratification. During spring-summer 2003, the maximum density gradient per $10 \mathrm{~m}$ water column was a linear function of the co-occurring salinity gradient, with strongest density gradients at stations that had been ice covered by $>30 \% 1$ month before sampling. The remaining variability in the density gradient is explained by temperature (GLM: density gradient $=0.00254+0.7255$ salinity gradient +0.07828 temperature gradient; $R^{2}=0.9889$ ).

diatoms by the time of sampling. At 26 mainly northern stations, krill did not contain any detectable $\mathrm{IPSO}_{25}$ and may, therefore, not have fed on ice diatoms within the last few weeks.

The $\mathrm{I} /(\mathrm{I}+\mathrm{H})$ ratios in krill stomach content did not show any relationship with body mass (Fig. 7e), which suggests that both small and large krill had equal access to sea ice diatoms. However, maximum I / $(\mathrm{I}+\mathrm{H})$ ratios were lower in muscle tissue than in the stomach content, and ratios dropped linearly with body size (Fig. 7f). This suggests that especially the tissue of larger krill was not in equilibration with a ice algae diet.

\subsection{Krill performance under different feeding conditions}

Based on our analysis, three groups of krill can be distinguished: those that had been feeding on ice diatoms (high $\mathrm{IPSO}_{25}$ content), those that had been feeding on open water diatoms favoured by conditions at the receding ice edge (high HBI III content) and those that did not feed substantially on either of these diatoms (no/low $\mathrm{IPSO}_{25}$ or HBI III content). To establish whether one of these feeding histories gave krill an advantage in their condition and performance, we tested three indicators: their mass-length ratio, the size of their digestive gland and their growth rate. However, as each of these indicators correlates with krill body size, we present the residuals of the indicator-to-body size regression rather than absolute values (i.e. size of digestive gland-tototal mass regressions, growth rate-to-length regression and mass-to-length regression). Using this approach, we found that krill were in best condition near the ice edge in the eastern Scotia Sea (station 47) with positive residuals for all three indicators (Fig. 8a-c). Krill sampled at the ice edge in the central Scotia Sea (stations 20,31) and at South Georgia (stations 56-61) showed positive residuals for at least two of these parameters. Overall, the residuals of the krill masslength regression were mostly positive in the central and eastern Scotia Sea and at South Georgia, but negative in the western Scotia Sea. This is likely due to local differences in the food availability, as indicated by the significant positive relationship between mass-residual and in situ chl $a$ concentration (Fig. 8d). On average, a high $\mathrm{IPSO}_{25}$ content in krill was associated with low chl $a$ concentrations and therefore "below-average" krill body mass, while a high HBI III content in krill co-occurred with medium chl $a$ concentrations and more often with "above-average" body mass (Fig. 8d).

\subsection{Recruitment of large calanoid copepods}

Another important group of pelagic grazers in the Southern Ocean are calanoid copepods, e.g. the high-latitude species Calanoides acutus and Calanus propinquus. While HBIs have not been measured in these species, their overall abundance and age structure gives some information about suitable feeding grounds. For both species, abundances were highest at South Georgia and in the south-eastern Scotia Sea (Fig. S3). The latter site was dominated by young development stages (CI-III), which indicates recent successful recruitment (Fig. 8e, f). At South Georgia, the population was older, but also dominated by new recruits (CIV). In contrast, in the western Scotia Sea copepod abundances were low, and the population consisted of "overwintered" copepodite stages (CV and females), suggesting that recruitment was delayed or had failed.

\section{Discussion}

\subsection{Evaluating the HBI approach}

Knowledge of the role of ice-algae- vs. phytoplanktonproduced carbon for higher trophic levels is central to our understanding of polar ecosystems. However, reliable estimates are difficult to achieve. Firstly, traditional trophic markers such as fatty acids, accessory pigments or taxonomy are of limited use as diatoms often dominate both communities with few species being obligate ice inhabitants (Arrigo, 2017). Secondly, approaches that allow the separation of the two sources based on non-conservative tracers, including bulk- or compound-specific stable isotope analysis, rely on numerous assumptions that are not always met in practice (Budge et al., 2008). An example is isotopic fractionation, where the $\delta^{13} \mathrm{C}$ values of fatty acids derived from diatoms, and not produced de novo by the consumer (e.g. $16: 4(n-1)$ or $20: 5(n-3))$ are usually assumed to remain unchanged across trophic levels (e.g. Budge et al., 2008; Wang et al., 2015; Kohlbach et al., 2017). However, laboratory and field studies have shown significant isotopic fractionation $(-4$ to 

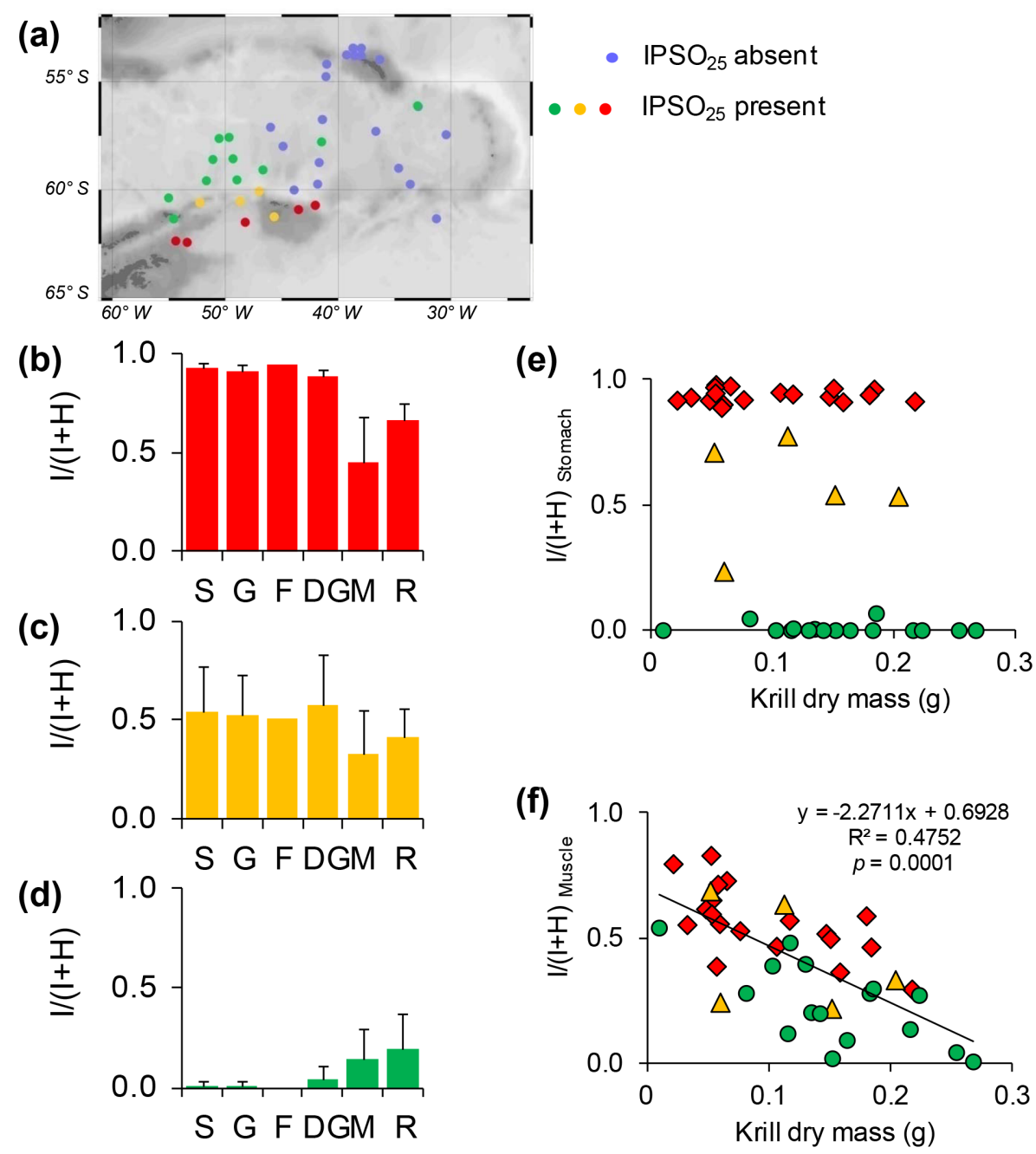

Figure 7. E. superba: multiple scenarios of krill feeding history on ice diatoms. (a) Location of stations where IPSO 25 was present in krill (red - Scenario 1; amber - Scenario 2; green - Scenario 3) or absent (purple). (b) Scenario 1: Krill are mainly feeding on ice diatoms. $\mathrm{I} /(\mathrm{I}+\mathrm{H})$ ratios are high $(>0.9)$ in stomach $(\mathrm{S})$, gut $(\mathrm{G})$, faecal pellets $(\mathrm{F})$ and digestive gland $(\mathrm{DG})$, but lower $(0.4-0.7)$ in muscles $(\mathrm{M})$ and rest of the body $(\mathrm{R})$. (c) Scenario 2: Krill are feeding on a mixture of ice diatoms and open water diatoms. I / (I $+\mathrm{H})$ ratios are moderate $(\sim 0.5)$ in stomach, gut, faecal pellets and digestive gland, but lower (0.3-0.4) in muscles and rest of the body. (d) Scenario 3: Krill are feeding on open water diatoms, but fed on ice diatoms in the past. I / $(\mathrm{I}+\mathrm{H})$ ratios are very low $(<0.1)$ in stomach, gut and digestive gland, but higher $(0.1-0.2)$ in muscles and rest of the body. (e, f) The effect of krill body size on their feeding on ice diatoms. I / (I $+\mathrm{H})$ ratios are presented separately for krill stomach content and muscle. The regression line indicates the overall negative relationship between $\mathrm{I} /(\mathrm{I}+\mathrm{H})_{\mathrm{Muscle}}$ and krill body weight. Colour of symbols in accordance with panels (b-d): red indicates krill that fed currently on ice diatoms; yellow indicates krill that fed currently on a mixture of ice and open water diatoms; green indicates krill that fed currently on open water diatoms. Individuals ranged from 16 to $42 \mathrm{~mm}$ in standard 3 body length $[L]$ and from 0.01 to $0.27 \mathrm{~g}$ in dry mass $[M]\left(M=1 \times 10^{-6} L^{3.2452}, R^{2}=0.9707\right)$. Each symbol represents $3-15$ pooled individuals of the same body length.

$-1 \%$ ) in polyunsaturated fatty acids between diet and consumer as well as a gradual depletion in the ${ }^{13} \mathrm{C}$ content of fatty acids upward through the food chain (Bec et al., 2011; Gladyshev et al., 2012, and references therein). If this isotopic fractionation remains unaccounted for, the contribution of the isotopically lighter source is overestimated and this bias increases with shorter isotopic distance between the endmembers (Bec et al., 2011). Based on data obtained from
Antarctic krill by Kohlbach et al. (2017, their Tables 3 and 6 ), the ice algae source of $20: 5(n-3)$ increased from 64 to $89 \%$ in larvae, from 46 to $70 \%$ in juveniles and from none to $7 \%$ in adults if a fractionation of $-1.5 \%$ between diatoms and grazer was implemented, according to Bec et al. (2011). This illustrates that the interpretation of fatty-acid-specific stable isotope data can be severely skewed if possible "diges- 

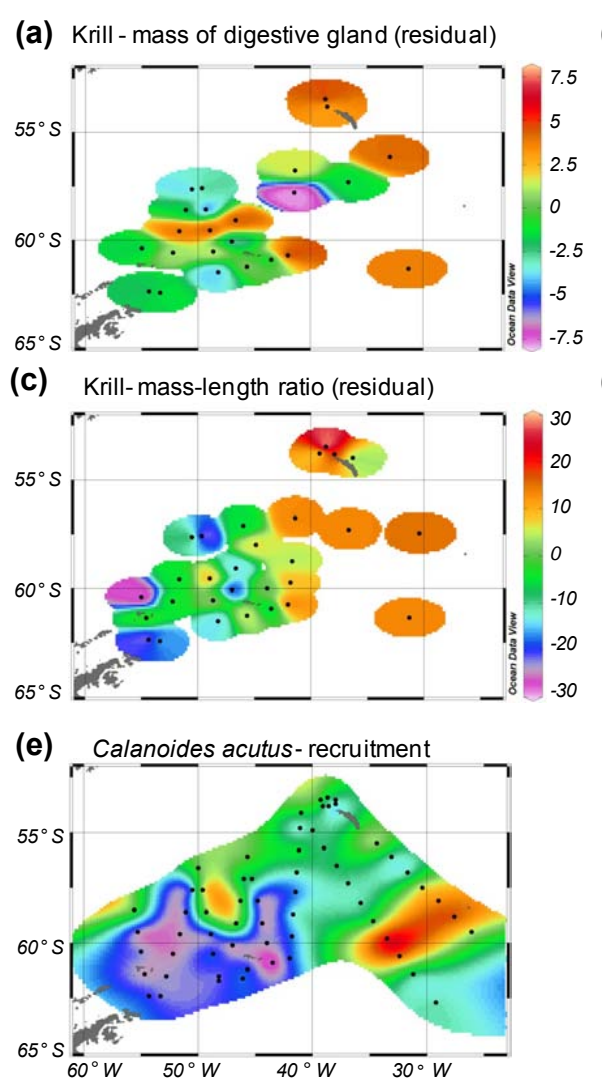

(b) Krill - growth rate (residual)

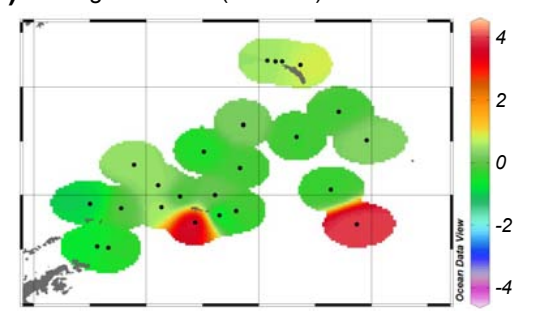

(d) $40 \quad y=30.656 x-49.914$
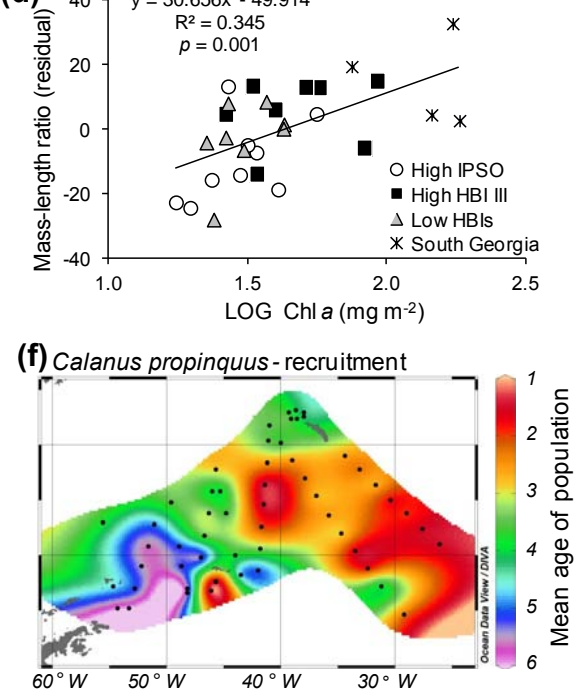

Figure 8. Local differences in the performance of krill (Euphausia superba) and large calanoid copepods (Calanoides acutus, Calanus propinquus) as indicated by their body reserves, growth and recruitment. To account for differences in krill body length, residuals rather than absolute values are presented. Residuals were calculated as positive or negative deviations from the relationship between the index of body condition $(y)$ and krill length $(x)$. Positive values denote "above-average" body conditions for their size, while negative values suggest "below-average" body conditions. (a) Residual of the mass of the digestive gland. $y=85.234 x+2.5386 ; R^{2}=0.7271, n=25$. (b) Residual of the krill growth rate in mass, based on original data from Atkinson et al. (2006). $y=65586 x^{-3.069} ; R^{2}=0.3265, n=24$. (c) Residual of the krill mass-length ratio. $y=0.0016 x^{3.2479}, R^{2}=0.8627, n=29$. (d) Overall linear regression between the residuals of the krill masslength ratio (panel c) and the availability of food, indicated by the integrated chl $a$ concentration in the upper $100 \mathrm{~m}$ water column. Krill from different locations are distinguished by their $\mathrm{IPSO}_{25}$ - or HBI III content: "high $\mathrm{PPSO}_{25}$ " (>30 ng g $\mathrm{g}^{-1}$ ), "high HBI III" (>100 ng g $\mathrm{g}^{-1}$ ), "low IPSO $_{25}$ and HBI III" ( $\left.<100 \mathrm{ng} \mathrm{g}^{-1}\right)$ and "South Georgia" $\left(<100 \mathrm{ng} \mathrm{g}^{-1}\right)$. Each symbol represents 3-15 pooled individuals of the same body length. (e) Recruitment of Calanoides acutus. (f) Recruitment of Calanus propinquus. To calculate the mean age of the population, six copepodite stages of increasing age were considered: first, second, third, fourth, fifth and sixth. Low numbers indicate a young age of the population, dominated by new recruits (stage 1-3). Late copepodite stages (stage 5-6) represent the old, overwintered generation.

tive" ${ }^{13} \mathrm{C}$ depletion of fatty acids is not considered (Gladyshev et al., 2012).

In contrast to fatty acids, where one marker (e.g. 20 : $5(n-3))$ carries the mixed isotopic signal from two food sources with additional fractionation within the grazer, the HBI approach is more straightforward. Here, two independent markers exist, one for ice algae (IPSO $\left.{ }_{25}\right)$ and one for phytoplankton (HBI III). Thus, if IPSO $_{25}$ occurred in krill in the present study, it unambiguously indicated their consumption of ice algae. Moreover, the relative abundance of $\mathrm{IPSO}_{25}$ and HBI III $(\mathrm{I} /(\mathrm{I}+\mathrm{H}))$ remained the same during transfer from krill stomach to the digestive gland (Fig. 7), which suggests that there was no selective absorption or degradation within the grazer. This is in line with laboratory experiments which showed near-identical HBI ratios in the brine shrimp Artemia sp. and its food (Brown and Belt, 2017). Thus, key advantages of the HBI approach are the existence of a sea ice proxy and its open water counterpart as well as minimal signature alterations by the consumer.

However, disadvantages of the HBI approach may arise from the generally lower abundance of these markers. While fatty acids are ubiquitous to marine life, HBIs are only produced by certain diatom species (Brown et al., 2014; Belt et al., 2017, and references therein). Four such species are currently known to produce the Arctic sea ice proxy $\mathrm{IP}_{25}$ (Brown et al., 2014), while in the Southern Ocean so far only one diatom species has been identified as a source of $\mathrm{IPSO}_{25}$ (Berkeleya adeliensis; Belt et al., 2016). The four 
Arctic source species are considered omnipresent in sea ice, however, and the application of $\mathrm{IP}_{25}$ as a proxy for palaeo Arctic sea ice reconstructions is well established (Belt and Müller, 2013). In contrast, research effort on HBIs in the Southern Ocean started more recently and initial findings require further confirmation. For instance, the known Antarctic source of $\mathrm{IPSO}_{25}$, B. adeliensis, is commonly associated with landfast ice and blooms in spring-early summer, which may limit its use as a sea ice proxy in oceanic settings or during winter (Belt et al., 2016). However, sediment cores, sea ice samples, water samples and Antarctic predators indicate a widespread occurrence of IPSO $_{25}$, including coastal and open ocean regions and samples obtained in summer and winter (this study; Massé et al., 2011; Goutte et al., 2013; Collins et al., 2013). This suggests co-production of IPSO $_{25}$ by as yet unidentified source species or by $B$. adeliensis also inhabiting non-coastal sea ice.

The proportion of $\mathrm{IPSO}_{25}$ in the combined $\mathrm{IPSO}_{25}$ and HBI III pool $(\mathrm{I} /(\mathrm{I}+\mathrm{H})$ as presented in this study) is only a relative indicator of ice-algae- vs. phytoplankton-produced carbon. A translation into carbon values would require that the particulate organic carbon (POC)-to-HBI ratio is estimated for the local endmembers (ice algae, phytoplankton) and that $\mathrm{I} /(\mathrm{I}+\mathrm{H})$ ratios are calibrated with known proportions of these endmembers. Such calibration has been carried out for ratios of pelagic vs. sympagic HBIs common in the Arctic via the so-called HBI fingerprint ("H-print"; Brown and Belt, 2017), and subsequently applied to obtain quantitative estimates of ice-derived carbon in Arctic amphipods (Brown et al., 2017). However, in this study we did not assess the absolute amount of carbon that krill acquire from ice algae. Instead we aimed for a mechanistic understanding of the role of sea ice for grazers such as krill, considering both carbon production within sea ice and conditioning effects of sea ice that promote phytoplankton blooms.

After the initial application of HBIs as trophic markers in Southern Ocean food web studies by Goutte et al. (2013, 2014a, b), our results provide three lines of evidence for the robustness of this approach: first, the carbon isotopic signatures $\left(\delta^{13} \mathrm{C}\right)$ of $\mathrm{IPSO}_{25}$ and HBI III confirm their different origins in sympagic vs. pelagic diatoms (Table 1). Second, given our open water set of sampling stations, both HBIs occurred in highest concentrations in suspended matter near the retreating ice edge; however, they were associated with different oceanographic conditions. IPSO ${ }_{25}$ coincided with sea ice cover and low temperatures, while HBI III peaked where meltwater-driven stratification and enhanced chl $a$ concentrations indicate favourable conditions for phytoplankton growth (Fig. 5). Third, there was a spatial overlap in the occurrence of HBIs in suspended matter and krill, which points to a direct trophic transfer (Fig. 4). The $\mathrm{I} /(\mathrm{I}+\mathrm{H})$ ratios in krill stomachs, and therefore the dietary role of ice diatoms, decreased with the stations distance from the ice edge (Fig. 7). In conclusion, the HBI approach has delivered plausible results and overcomes some of the limitations of other trophic markers. Therefore, we consider it a suitable tool to assess the role of ice algae and ice-conditioned phytoplankton for Southern Ocean grazers. However, given the different strengths and weaknesses of HBI, fatty-acid-specific stable isotopes and other trophic markers, their combined application is likely to increase the robustness of the results and the amount of detail revealed (Schmidt et al., 2006).

\subsection{The role of ice-algae-produced carbon for krill nutrition}

Trophic markers such as HBIs, fatty acids or stable isotopes have different residence times in the various body compartments of consumers depending on their turnover and growth rates (Schmidt and Atkinson, 2016). In the krill muscle, for instance, turnover is relatively slow and markers may be conserved within this tissue for several weeks after their uptake. This allows us to gain information about the consumer's feeding history. On the down side, time-integrated signals from muscle tissue cannot be related to specific environmental conditions at the time of sampling or mobile features such as the retreating ice edge. This is especially true in the Scotia Sea, where local retention as well as large-scale advection of krill may occur (Meyer et al., 2017). We overcame this problem by analysing HBIs in the krill stomach. The stomach content has a much faster turnover time than muscle tissue, varying between $45 \mathrm{~min}$ and $\sim 10 \mathrm{~h}$ in krill (Schmidt and Atkinson, 2016). This "snapshot" of their diet permits a direct comparison between the uptake of IPSO $_{25}$ and HBI III by krill and the occurrence of these markers in the suspended matter of their sampling location.

At five stations near the ice edge, krill stomachs contained a higher proportion of ice algae $\left(\mathrm{I} /(\mathrm{I}+\mathrm{H})_{\text {Stomach }}\right.$ : $0.93 \pm 0.03)$ than the suspended matter in surface waters $\left(\mathrm{I} /(\mathrm{I}+\mathrm{H})_{\mathrm{SM}}: 0.68 \pm 0.21\right)$. Up to $200 \mathrm{~km}$ north of the ice edge, a mixture of ice algae and phytoplankton was found in krill stomachs (I / $(\mathrm{I}+\mathrm{H})_{\text {Stomach }}$ : $\left.0.56 \pm 0.24\right)$, while $\mathrm{IPSO}_{25}$ was not detected in suspended matter from surface waters. These observations suggest that krill fed preferentially on ice algae and sampled them below the upper mixed layer, either during their diurnal vertical migration or in special foraging trips towards the benthos (Schmidt et al., 2011). At station 8, for instance, a high $\mathrm{I} /(\mathrm{I}+\mathrm{H})$ ratio coincided with lithogenic particles in krill stomachs, which may have been ingested at the seabed (Schmidt et al., 2011). About 200-600 km north of the ice edge, $\mathrm{IPSO}_{25}$ was found in krill muscle tissue, but not in their stomachs. These results indicate that krill had been feeding on ice algae in the past, but subsequently relied on phytoplankton. Overall, IPSO ${ }_{25}$ was detected in krill from 21 stations across the western and central Scotia Sea, confirming the widespread uptake of ice algae as a food source.

We found different trends between krill body mass and their $\mathrm{I} /(\mathrm{I}+\mathrm{H})$ ratios in stomach content and muscle. Small krill were equilibrated with the ice algae diet, having high $\mathrm{I} /(\mathrm{I}+\mathrm{H})$ ratios in both stomach and muscle, while larger 
krill had high $\mathrm{I} /(\mathrm{I}+\mathrm{H})$ ratios only in their stomachs and not in their muscles (Fig. 7). This suggests that larger krill did not feed long enough on ice algae to reach equilibrium between diet and body tissue. Most likely, ice algae became more accessible to krill when the ice started to melt (Jia et al., 2016). The $\mathrm{IPSO}_{25}$ extracted from krill was enriched in $\delta^{13} \mathrm{C}$ (Table 1), as is typical for material from interior sea ice (McMinn et al., 1999; Wang et al., 2014) that is only within reach of krill when the algae are released into the water column. A carbon budget of ice algae in the Canadian Arctic in spring showed that $>65 \%$ of the biomass, released from sea ice into the upper water column, remained suspended (Michel et al., 1996). However, the high variability in chl $a$ residence time (mean: $31 \pm 33$ days) and sinking rate (mean: $1.4 \pm 1.5 \mathrm{~m} \mathrm{~d}^{-1}$ ) illustrates the dual fate of ice algae (Michel et al., 1996). While some algae rapidly sink out of the euphotic zone and efficiently transfers carbon to the benthos (e.g. Riebesell et al., 1991; Renaud et al., 2007), others remain suspended over several weeks and can aid the nutrition of pelagic grazers (Michel et al., 1996; Smik et al., 2016). In any case, the trophic importance of ice algae extends beyond the period of their maximum production in sea ice (Michel et al., 1996). Here, the ice proxy $\mathrm{IPSO}_{25}$ revealed that ice algae can be an important food source for krill even several weeks after the ice cover has disappeared.

In the western and central Scotia Sea, phytoplankton concentrations were low and the community was dominated by small size classes $(<12 \mu \mathrm{m})$ during spring and summer 2002/2003 (Fig. 3, Korb et al., 2005). This may explain why krill continued feeding on ice algae even after the algae had descended out of surface waters. In some years, phytoplankton blooms seem not to take off in this region, and light limitation, iron deficiency and grazing pressure have been discussed as potential reasons (Lancelot et al., 1993; Korb et al., 2005; Park et al., 2010). Our study period coincided with a negative phase of the Southern Annular Mode (http://www.nerc-bas.ac.uk/icd/gjma/sam.html, last access: 24 March 2018), which is characterised by reduced strength and duration of wind mixing events (Saba et al., 2014). This led to shallow mixed layers and deep euphotic depths, constituting favourable light conditions for phytoplankton growth (Fig. 3, Korb et al., 2005). However, 2002/2003 was also a year of good krill recruitment (Atkinson et al., 2014) and high krill densities occurred especially in the western and central Scotia Sea (authors' unpublished observations). At seven stations in the central Scotia Sea, krill contained high amounts of HBI III (110-3460 $\mathrm{ng} \mathrm{g}^{-1}$, especially station 22; Fig. 4), even though there was little evidence of HBI III in the suspended matter in surface waters at that time. This suggests that diatom species favoured within the MIZ were produced in the central Scotia Sea but did not accumulate, possibly due to high grazing losses. A 13-year data set of satellitederived chl $a$ concentrations shows that the area where krill contained high amounts of HBI III (Fig. 4e) matches the re- gion with exceptionally low surface chl $a$ concentrations in the central Scotia Sea in the 2002/2003 season (Fig. 2e).

The combination of high krill densities and low food availability can lead to competition-induced starvation (Ryabov et al., 2017). Such an effect may be seen in the krill's weightto-length ratios. At most stations in the western and central Scotia Sea, krill were lighter than predicted from their body length, showing negative residuals from the masslength regression (Fig. 8c). These stations largely coincided with those where krill contained the ice proxy $\mathrm{IPSO}_{25}$. However, the presence of $\mathrm{IPSO}_{25}$ in krill distant from the ice edge may simply indicate a shortage of their main summer food - phytoplankton. More relevant is the link between $\mathrm{IPSO}_{25}$ and krill performance at stations near the ice edge, where ice algae were prominent in their stomachs. Of these six stations, two provided good feeding conditions for krill (positive residuals, stations 20,31), while four did not (negative residuals, stations $5,6,18,30$ ). This is in line with other studies showing high variability in food supply from sea ice (Marschall et al., 1988; Michels et al., 2008; Schmidt et al., 2012, 2014; Meyer et al., 2017). Local differences in snow cover, ice thickness, ice rafting or time of ice formation can lead to different concentrations of ice algae in the bottom ice layer (Fritsen et al., 2008; Meiners et al., 2012). However, below-average krill body mass was even found in individuals that contained high concentrations of $\mathrm{IPSO}_{25}$ (stations 5, 18), while krill with positive residuals from the mass-length regression showed high concentrations of both $\mathrm{IPSO}_{25}$ and HBI III (station 30) or mainly HBI III (station 20). This confirms the essential role of phytoplankton blooms for krill performance in spring (Cuzin-Roudy et al., 1992; Schmidt et al., 2012).

\subsection{The role of sea-ice-conditioned phytoplankton blooms}

Offshore regions of the Southern Ocean are often characterised by high-nitrate-low-chlorophyll conditions due to the shortage of iron. However, in the Scotia Sea primary and secondary production can be comparatively high (Atkinson et al., 2008; Park et al., 2010). In 2002/2003, late sea ice retreat coincided with a negative phase of the Southern Annular Mode, volcanic activity at Mount Belinda $(\sim 80 \mathrm{~km}$ east off station 50) and high krill abundances (authors' unpublished observations; Patrick et al., 2005; Ward et al., 2006). This would have provided favourable light conditions and iron (Korb et al., 2005; Browning et al., 2014; Schallenberg et al., 2015), but also enhanced grazing impact and nutrient recycling (Schmidt et al., 2016). Perhaps as a consequence, the phytoplankton bloom was unusually long-lasting and intensive across the East Scotia Ridge, but weaker than average in the central Scotia Sea (Fig. 2; Park et al., 2010). Sea ice retreat can assist phytoplankton growth due to the freshness of the meltwater, following brine rejection during ice formation. The low-salinity (hence low-density) input enhances water 
column stability, thereby reducing vertical mixing and retaining phytoplankton in an optimal light environment (Smith and Nelson, 1986). However, meltwater lenses do not always lead to ice edge blooms. In the eastern Scotia Sea, phytoplankton blooms propagated behind the receding ice edge over hundreds of kilometres and for several months (Fig. 2). In contrast, in the western and central Scotia Sea, strong density gradients occurred upon ice retreat but phytoplankton did not accumulate. A reason for these differences may be the speed of ice retreat (Constable et al., 2003). Between midDecember and mid-February, ice retreated at $\sim 1.7 \mathrm{~km} \mathrm{~d}^{-1}$ in the west and at $11.7 \mathrm{~km} \mathrm{~d}^{-1}$ in the east (authors' unpublished data). Rapid ice retreat enhances the volume and spatial extent of meltwater input and therefore the likelihood that stratification persists long enough for marked phytoplankton growth and accumulation (Smith and Nelson, 1986). Other factors controlling phytoplankton development along the receding ice edge include iron deficiency and grazing pressure by zooplankton (Tréguer and Jacques, 1992; Lancelot et al., 1993).

Ice edge phytoplankton blooms have been reported throughout the Arctic (Perrette et al., 2011) and from the Ross Sea, Weddell Sea, Scotia Sea, Prydz Bay and the Pacific sector of the Southern Ocean (e.g. Smith and Nelson, 1986; Constable et al., 2003, and references therein). However, the overall importance of primary production in the MIZ is still debated (Vancoppenolle et al., 2013). Originally, the MIZ was considered a major hotspot for autotrophic production in the Southern Ocean (Smith and Nelson, 1986). Subsequent analysis of satellite data, however, suggests that phytoplankton blooms in the MIZ are largely suppressed at high wind speed, and, even with lower winds, blooms occur only over one-third of the MIZ (Fitch and Moore, 2007). Therefore, area-normalised primary production rates calculated from ocean colour are on average only slightly higher in the MIZ than in the permanently ice-free Southern Ocean (Arrigo et al., 2008). This has led to the conclusion that while the MIZ has the potential to be productive, physical conditions are seldom conducive to the development of intense, longer-lived phytoplankton blooms (Arrigo et al., 2008). Conversely, high abundances of zooplankton, seabirds and whales are characteristic of the MIZ and confirm enhanced biological activity and the importance of this region for the food web (Brown and Lockyer, 1984; Ichii et al., 1990; Ainley et al., 2017).

Antarctic krill sampled in the previously ice covered eastern Scotia Sea had high HBI III concentrations and aboveaverage body mass (i.e. positive residuals in Fig. 8c). The occurrence of HBI III in krill tissue often coincided with medium to high chl $a$ concentrations in the water column (Fig. 8d). Therefore, enhanced krill performance in the east is most likely a result of higher food concentrations. A number of studies have previously found chl $a$ concentrations to represent a reliable predictor of krill growth and maturation (Ross et al., 2000; Atkinson et al., 2006; Schmidt et al., 2012; Meyer et al., 2017). Krill from the most southerly station of the eastern transects (station 47) were in similarly good conditions to those at South Georgia, showing high body mass, large digestive gland and exceptionally high growth rates when adjusted for their length. This is unexpected considering that, at the time of sampling, only 2 weeks of elevated chl $a$ concentrations ( $>0.5 \mathrm{mg} \mathrm{m}^{-3}$ ) were recorded at station 47 , but $\sim 16$ weeks at South Georgia (based on ocean colour data; Fig. 2). A previous study revealed that krill can engage in "superfluous" feeding when food is abundant (Schmidt et al., 2012). This way, the food concentration in their digestive tract remains high and nutrient absorption per unit time is maximised. Consequently, krill can rapidly improve their body condition and advance in maturation (Schmidt et al., 2012). $\mathrm{IPSO}_{25}$ was not detected in krill from station 47 but was found in low concentrations in suspended matter at the neighbouring station closer to the ice edge (station 48). Station 47 had been ice-free for $\sim 20$ days when krill were sampled, which is approximately the turnover time of the Arctic sea ice proxy in zooplankton (Brown and Belt, 2012). Therefore, krill may have been feeding on ice algae at this station, but any indication of this via IPSO $\mathrm{P}_{25}$ was lost following their switch to phytoplankton.

A few copepod species inhabit Antarctic sea ice, but the biomass-dominant copepod grazers in high latitudes, Calanoides acutus and Calanus propinquus, are only loosely associated with sea ice, if at all (Arndt and Swadling, 2006). C. acutus shows reduced feeding activity within the ice and their offspring only occur in the MIZ or open waters (Atkinson and Shreeve, 1995; Burghart et al., 1999). In contrast, C. propinquus have been found feeding on ice algae and spawning below sea ice, but their populations likewise expand mainly in open waters (Atkinson and Shreeve, 1995; Burghart et al., 1999). Both species can complete their life cycle at South Georgia (Atkinson and Peck, 1988), which is permanently sea-ice-free. During our study period, the occurrence and recruitment of these species showed similarities to feeding behaviour and performance of Antarctic krill. In the western and central Scotia Sea, C. acutus and C. propinquus had low abundances and the populations were dominated by females and late copepodite stages representing the "old, overwintered" generation. This delay or failure of recruitment was likely caused by the lack of phytoplankton, as also indicated by krill feeding on sinking ice algae in open waters and their below-average body mass. Highest copepod abundances in the south-east coincided with the dominance of early copepodite stages (i.e. the "new" generation). This region of intensive copepod reproduction (stations 45, 50, 51, 52) matches high HBI III concentrations in suspended matter and enhanced krill performance in the wake of retreating sea ice. We therefore suggest that the MIZ is an important nursery ground for these large copepod species, in line with previous findings (Atkinson and Shreeve, 1995; Burghart et al., 1999). At South Georgia, the copepod populations of $C$. acutus and C. propinquus were further advanced in their seasonal development (dominated by medium copepodite stages 
of the "new" generation), but the overall abundances were similar to those in the south.

The weak, sporadic link between large calanoid copepods and ice algae in the Antarctic contrasts with conditions in the Arctic. Here ice algae serve as an important food source for spawning females of Calanus glacialis (Søreide et al., 2010; Durbin and Casas, 2013) and the early developmental stages of C. hyperboreus (Conover, 1988). Average primary production rates in sea ice are considered lower in the Southern Ocean than in the Arctic (Arrigo, 2017). In the Antarctic, $\sim 85 \%$ of sea ice is annual and needs to be newly inhabited every year (Stammerjohn and Maksym, 2017). However, as much of this sea ice forms over deep ocean, re-colonisation from the benthos or via lateral dispersion from perennial sea ice is unlikely, leaving the water column as the sole source (Arndt and Swadling, 2006). In contrast, Arctic sea ice covers comparatively shallow waters, and traditionally has a larger proportion of perennial sea ice, which increases the chances of re-colonisation. Another factor influencing productivity in sea ice is the level of irradiance available to primary producers (Meiners et al., 2012). Antarctic pack ice experiences some of the largest snowfall rates on Earth, while melt ponds are widespread in the Arctic (Vancoppenolle et al., 2013). The former attenuates light, whereas the latter efficiently transmits it to the underlying ocean.

\section{Conclusions}

Large parts of the Southern Ocean are characterised by low phytoplankton concentrations due to the lack of iron, strong vertical mixing or grazing and other losses. Our study suggests that in such areas, pelagic grazers may benefit from seasonal sea ice in two ways. Firstly, suspended or sinking ice algae can supplement their diet in spring and summer. Second, retreating sea ice enhances the likelihood of bloom formation due to shoaling of the mixed layer, supply of iron and/or release of a seeding population. Phytoplankton blooms initiated in the MIZ allow zooplankton to grow rapidly, gain body reserves and advance in their development. Therefore, current and future changes in sea ice will affect not only sympagic fauna but also zooplankton species that inhabit open waters adjacent to it. The analysis of two source-specific highly branched isoprenoids provided a useful tool to trace ice-produced and ice-conditioned food sources within pelagic grazers. Essential for their further application will be to resolve the spatial and temporal occurrence of the ice proxy $\mathrm{IPSO}_{25}$ and to gauge the carbonto-isoprenoid ratios of ice algae and phytoplankton. Development of the HBI trophic marker approach, alongside other methods, will help us to understand exactly how Arctic and Antarctic food webs depend on sea ice.
Data availability. The data that support the findings of this study are within the article and its Supplement.

\section{The Supplement related to this article is available online at https://doi.org/10.5194/bg-15-1987-2018-supplement.}

Competing interests. The authors declare that they have no conflict of interest.

Acknowledgements. We thank the officers, crew and scientists on board the RRS James Clark Ross for their professional support during JR82. We acknowledge the MODIS mission scientists and associated NASA personnel for the production of data in the Giovanni online data system. We thank Rebecca Korb for providing size-fractionated chl $a$ measurements, Nathan Cunningham for supplying oceanographic data, and Patricia Cabedo-Sanz and Lukas Smik for help with lab work. Comments from Kim Bernard, an anonymous reviewer and the Associate Editor Jack Middelburg were much appreciated. This study was supported by a research project grant (RPG-2014-021) awarded by the Leverhulme Trust (UK) to Simon T. Belt. Angus Atkinson was part-funded by NERC and Department for Environment, Food and Rural Affairs (DEFRA) grant NE/L 003279/1 (Marine Ecosystems Research Program).

Edited by: Jack Middelburg

Reviewed by: Kim Bernard and one anonymous referee

\section{References}

Ainley, D., Woehler, E. J., and Lescroël, A.: Birds and Antarctic sea ice, in: Sea Ice, edited by: Thomas, D. N., John Wiley \& Sons, Ltd, Chichester, 570-582, https://doi.org/10.1002/9781118778371.ch24, 2017.

Arndt, C. E. and Swadling, K. M.: Crustacea in Arctic and Antarctic sea ice: distribution, diet and life history strategies, Adv. Mar. Biol., 51, 197-315, https://doi.org/10.1016/S00652881(06)51004-1, 2006.

Arrigo, K.: Sea ice as a habitat for primary producers, in: Sea Ice, edited by: Thomas, D. N., John Wiley \& Sons, Ltd, Chichester, 352-369, https://doi.org/10.1002/9781118778371.ch14, 2017.

Arrigo, K. R., van Dijken, L. G. L., and Bushinsky, S.: Primary production in the Southern Ocean, 1997-2006, J. Geophys. Res., 113, C08004, https://doi.org/10.1029/2007JC004551, 2008.

Atkinson, A. and Peck, J. M.: A summer-winter comparison of zooplankton in the oceanic area around South Georgia, Polar Biol., 8, 463-473, https://doi.org/10.1007/BF00264723, 1988.

Atkinson, A. and Shreeve, R. S.: Response of the copepod community to a spring bloom in the Bellingshausen Sea, Deep-Sea Res. II, 42, 1291-1311, https://doi.org/10.1016/0967-0645(95)00057W, 1995.

Atkinson, A., Shreeve, R., Hirst, A. G., Rothery, P., Tarling, G., Pond, D., Korb, R. E., Murphy, E. J., and Watkins, J. 
L.: Natural growth rates in Antarctic krill (Euphausia superba): II. Predictive models based on food, temperature, body length, sex, and maturity stage, Limnol. Oceanogr., 51, 973-987, https://doi.org/10.4319/lo.2006.51.2.0973, 2006.

Atkinson, A., Siegel, V., Pakhomov, E. A., Rothery, P., Loeb, V., Ross, R. M., Quetin, L. B., Schmidt, K., Fretwell, P., Murphy, E. J., Tarling, G. A., and Fleming, A. H.: Oceanic circumpolar habitats of Antarctic krill, Mar. Ecol. Prog. Ser., 362, 1-32, https://doi.org/10.3354/meps07498, 2008.

Atkinson, A., Hill, S. L., Barange, M., Pakhomov, E. A., Raubenheimer, D., Schmidt, K., Simpson, S. J., and Reiss, C.: Sardine cycles, krill declines, and locust plagues: Revisiting 'wasp-waist' food webs, Trends Ecol. Evol., 29, 309-316, https://doi.org/10.1016/j.tree.2014.03.011, 2014.

Barnes, D. K. A. and Tarling, G. A.: Polar oceans in a changing climate, Current Biol., 27, 454-460, https://doi.org/10.1016/j.cub.2017.01.045, 2017.

Bec, A., Perga, M.-E., Koussoroplis, A., Bardoux, G., Desvilettes, C., Bourdier, G., and Mariotti, A.: Assessing the reliability of fatty acid-speific stable isotope analysis for trophic studies, Meth. Ecol. Evolut., 2, 651-659, https://doi.org/10.1111/j.2041210X.2011.00111.x, 2011.

Belt, S. T. and Müller, J.: The Arctic sea ice biomarker $\mathrm{IP}_{25}$ : a review of current understanding, recommendations for future research and applications in Palaeo sea ice reconstructions, Quat. Sci. Rev., 79, 9-25, https://doi.org/10.1016/j.quascirev.2012.12.001, 2013.

Belt, S. T., Brown, T. A., Navarro-Rodriguez, A., Cabedo-Sanz, P., Tonkin, A., and Ingle, R.: A reproducible method for the extraction, identification and quantification of the Arctic sea ice proxy $\mathrm{IP}_{25}$ from marine sediments, Analyt. Meth., 4, 705-713, 2012.

Belt, S. T., Cabedo-Sanz, P., Smik, L., Navarro-Rodriguez, A., Berben, S. M. P., Knies, J., and Husum, K.: Identification of paleo Arctic winter sea ice limits and the marginal ice zone: optimised biomarker-based reconstructions of the late Quaternary Arctic sea ice, Earth Planet. Sci. Lett., 431, 127-139, https://doi.org/10.1016/j.epsl.2015.09.020, 2015.

Belt, S. T., Smik, L., Brown, T. A., Kim, J.-H., Rowland, S. J., Allen, C. S., Gal, J.-K., Shin, K.-H., Lee, J. I., and Taylor, K. W. R.: Source identification and distribution reveals the potential of the geochemical Antarctic sea ice proxy $\mathrm{IPSO}_{25}$, Nat. Comms., 7, 12655, https://doi.org/10.1038/ncomms12655, 2016.

Belt, S. T., Brown, T. A., Smik, L., Tatrek, A., Wiktor, J., Stowasser, G., Assmy, P., Allen, C. S., and Husum, K.: Identification of $\mathrm{C}_{25}$ highly branched isoprenoid (HBI) alkenes in diatoms of the genus Rhizosolenia in polar and subpolar marine phytoplankton, Org. Geochem., 110, 65-72, https://doi.org/10.1016/j.orggeochem.2017.05.007, 2017.

Bester, M. N., Bornemann, H., and McIntyre, T.: Antarctic marine mammals and sea ice, in: Sea Ice, edited by: Thomas, D. N., John Wiley \& Sons, Ltd, Chichester, 534-555, https://doi.org/10.1002/9781118778371.ch22, 2017.

Bluhm, B., Swadling, K. M., and Gradinger, R.: Sea ice as habitat for macrograzers, in: Sea Ice, edited by: Thomas, D. N., John Wiley \& Sons, Ltd, Chichester, 394-414, https://doi.org/10.1002/9781118778371.ch16, 2017.

Brown, S. G. and Lockyer, C. H.: Whales, in: Antarctic Ecology, edited by: Laws, R. M., Vol. 2, Academic Press, London, 717$781,1984$.
Brown, T. A. and Belt, S.: Closely linked sea ice-pelagic coupling in the Amundsen Gulf revealed by the sea ice diatom biomarker $\mathrm{IP}_{25}$, J. Plankton Res., 34, 647-654, https://doi.org/10.1093/plankt/fbs045, 2012.

Brown, T. A. and Belt, S.: Biomarker-based H-Print quantifies the composition of mixed sympagic and pelagic algae consumed by Artemia sp., J. Exp. Mar. Biol. Ecol., 488, 32-37, https://doi.org/10.1016/j.jembe.2016.12.007, 2017.

Brown, T. A., Belt, S., Tatarek, A., and Mundy, C. J.: Source identification of the Arctic sea ice proxy $\mathrm{IP}_{2}$ 5, Nat. Commun., 5, 4197, https://doi.org/10.1038/ncomms5197, 2014.

Brown, T. A., Assmy, P., Hop, H., Wold, A., and Belt, S. T.: Transfer of ice algae carbon to ice-associated amphipods in the highArctic pack ice environment, J. Plankton Res., 39, 664-674, https://doi.org/10.1093/plankt/fbx030, 2017.

Browning, T. J., Bouman, H. A., Henderson, G. M., Mather, T. A., Pyle, D. M., Schlosser, C., Woodward, E. M. S., and Moore, C. M.: Strong responses of Southern Ocean phytoplankton communities to volcanic ash, Geophys. Res. Lett., 41, 2851-2857, https://doi.org/10.1002/2014GL059364, 2014.

Budge, S. M., Wooller, M. J., Springer, A. M., Iverson, S. J., McRoy, C. P., and Divoky, G. J.: Tracing carbon flow in an arctic marine food web using fatty acid-stable isotope analysis, Oecologia, 157, 117-129, https://doi.org/10.1007/s00442-008-1053-7, 2008.

Burghart, S. E., Hopkins, T. L., Vargo, G. A., and Torres, J. J.: Effects of rapidly receding ice edge on the abundance, age structure and feeding of three dominant calanoid copepods in the Weddell Sea, Antarctica, Polar Biol., 22, 279-288, https://doi.org/10.1007/S003000050421, 1999.

Caron, D. A., Gast, R. J., and Garneau, M.-E.: Sea ice as habitat for micrograzers, in: Sea Ice, edited by: Thomas, D. N., John Wiley \& Sons, Ltd, Chichester, 370-393, https://doi.org/10.1002/9781118778371.ch15, 2017.

Cavalieri, D. J., Parkinson, C. L., Gloersen, P., and Zwally, H. J.: Sea Ice Concentrations from Nimbus-7 SMMR and DMSP SSM/I-SSMIS Passive Microwave Data, Version 1, [Indicate subset used], Boulder, Colorado USA, NASA National Snow and Ice Data Center Distributed Active Archive Center, https://doi.org/10.5067/8GQ8LZQVL0VL, 1996 (updated 2014).

Collins, L. G., Allen, C. S., Pike, J., Hodgson, D. A., Weckström, K., and Massé, M.: Evaluating highly branched isoprenoid (HBI) biomarkers as a novel Antarctic sea-ice proxy in deep ocean glacial age sediments, Quat. Sci. Rev., 79 87-98, https://doi.org/10.1016/j.quascirev.2013.02.004, 2013.

Conover, R. J.: Comparative life histories in the genera Calanus and Neocalanus in high latitudes of the Northern Hemisphere, Hydrobiologia, 167, 127-142, https://doi.org/10.1007/BF00026299, 1988.

Constable, A. J., Nicol, S., and Strutton, P. G.: Southern Ocean productivity in relation to spatial and temporal variation in the physical environment, J. Geophys. Res., 108, 1-10, https://doi.org/10.1029/2001JC001270, 2003.

Constable, A. J., Melbourne-Thomas, J., Corney, S. P., Arrigo, K. R., Barbraud, C., Barnes, D. K., Bindoff, N. L., Boyd, P. W., Brandt, A., Costa, D. P., Davidson, A. T., Ducklow, H. W., Emmerson, L., Fukuchi, M., Gutt, J., Hindell, M. A., Hofmann, E. E., Hosie, G. W., Iida, T., Jacob, S., Johnston, N. M., Kawaguchi, 
S., Kokubun, N., Koubbi, P., Lea, M. A., Makhado, A., Massom, R. A., Meiners, K., Meredith, M. P., Murphy, E. J., Nicol, S., Reid, K., Richerson, K., Riddle, M. J., Rintoul, S. R., Smith, W. O. Jr, Southwell, C., Stark, J. S., Sumner, M., Swadling, K. M., Takahashi, K. T., Trathan, P. N., Welsford, D. C., Weimerskirch, H., Westwood, K. J., Wienecke, B. C., Wolf-Gladrow, D., Wright, S. W., Xavier, J. C., and Ziegler, P.: Climate change and Southern Ocean ecosystems I: how changes in physical habitats directly affect marine biota, Glob. Change Biol., 20, 3004-3025, https://doi.org/10.1111/gcb.12623, 2014.

Cuzin-Roudy, J. and Labat, J. P.: Early summer distribution of Antarctic krill sexual development in the Scotia-Weddell region: A multivariate approach, Polar Biol., 12, 65-74, 1992.

Durbin, E. G. and Casas, M.: Early reproduction by Calanus glacialis in the Northern Bering Sea: the role of ice algae as revealed by molecular analysis, J. Plank. Res, 36, 523-541, https://doi.org/10.1093/plankt/fbt121, 2013.

Fitch, D. T. and Moore, J. K.: Wind speed influence on phytoplankton bloom dynamics in the Southern Ocean marginal ice zone, J. Geophys. Res., 112, C08006, https://doi.org/10.1029/2006JC004061, 2007.

Flores, H., van Franeker, J. A., Siegel, V., Haraldsson, M., Strass, V., Meester, E. H., Bathmann, U., and Wolff, W. J.: The association of Antarctic krill Euphausia superba with the under-ice habitat, PloS ONE, 7, e31775, https://doi.org/10.1371/journal.pone.0031775, 2012a.

Flores, H., Atkinson, A., Kawaguchi, S., Krafft, B. A., Milinevsky, G., Nicol, S., Reiss, C., Tarling, G. A., Werner, R., Bravo Rebolledo, E., Cirelli, V., Cuzin-Roudy, J., Fielding, S., Groeneveld, J. J., Haraldsson, M., Lombana, A., Marschoff, E., Meyer, B., Pakhomov, E. A., Rombolá, E., Schmidt, K., Siegel, V., Teschke, M., Tonkes, H., Toullec, J. Y., Trathan, P. N., Tremblay, N., Van de Putte, A. P., van Franeker, J. A., Werner, T.: Impact of climate change on Antarctic krill, Mar. Ecol. Prog. Ser., 458, 1-19, https://doi.org/10.3354/meps09831, 2012b.

Forcada, J. and Hoffman, J. I.: Climate change selects for heterozygosity in a declining fur seal population, Nature, 511, 462-465, https://doi.org/10.1038/nature13542, 2014.

Fraser, W. and Hoffmann, E.: A predator's perspective on causal links between climate change, physical forcing and ecosystem response, Mar. Ecol. Prog. Ser., 265, 1-15, https://doi.org/10.3354/meps265001, 2003.

Fritsen, C. H., Memmott, J., and Stewart, F. J.: Inter-annual seaice dynamics and micro-algal biomass in winter pack ice of Marguerite Bay, Antarctica, Deep-Sea Res. II, 55, 2059-2067, https://doi.org/10.1016/j.dsr2.2008.04.034, 2008.

Gladyshev, M. I., Sushchik, N. N., Kalachova, G. S., and Makhutova, O. N.: Stable isotope composition of fatty acids in organisms of different trophic levels in the Yenisei River, PloS ONE, 7, e34059, https://doi.org/10.1371/journal.pone.0034059, 2012.

Goutte, A., Cherel, Y., Houssais, M.-N., Klein, V., OzoufCostaz, C., Raccut, M., Robineau, C., and Massé, G.: Diatom-specific highly branched isoprenoids as biomarkers in Antarctic consumers, PloS ONE, 8, e56504, https://doi.org/10.1371/journal.pone.0056504, 2013.

Goutte, A., Charrassin, J.-B., Cherel, Y., Carravieri, A., De Grissac, S., and Massé, G.: Importance of ice algal production for top predators: new insights using sea-ice biomarkers, Mar. Ecol.
Prog. Ser., 513, 269-275, https://doi.org/10.3354/meps10971, 2014a.

Goutte, A., Cherel, Y., Ozouf-Costz, C., Robineau, C., Lanshere, J., and Massé, G.: Contribution of sea ice organic matter in the diet of Antarctic fishes: a diatom-specific highly branched isoprenoid approach, Polar Biol., 37, 903-910, https://doi.org/10.1007/s00300-014-1489-7, 2014b.

Grebmeier, J. M., Moore, S. E., Overland, J. E., Frey, K. E., and Gradinger, R.: Biological responses to recent Pacific Arctic sea ice retreat, Trans. Am. Geophys. Union, 91, 161-162, https://doi.org/10.1029/2010EO180001, 2010.

Hagen, W. and Auel, H.: Seasonal adaptations and the role of lipids in oceanic zooplankton, Zoology, 104, 313-326, https://doi.org/10.1078/0944-2006-00037, 2001.

Ichii, T.: Distribution of Antarctic krill concentrations exploited by Japanese krill trawlers and mink whales, Proc. NIPR Symp. Polar Biol., 3, 36-56, 1990.

Jia, Z., Swadling, K. M., Meiners, K. M., Kawaguchi, S., and Virtue, P.: The zooplankton food web under East Antarctic pack ice - A stable isotope study, Deep-Sea Res. II, 131, 189-202, https://doi.org/10.1016/j.dsr2.2015.10.010, 2016.

Kawaguchi, S., Nicol, S., and Press, A. J.: Direct effects of climate change on the Antarctic krill fishery, Fish. Manag. Ecol., 16, 424-427, https://doi.org/10.1111/j.1365-2400.2009.00686.x, 2009.

Kohlbach, D., Lange, B. A., Schaafsma, F. L., David, C., Vortkamp, M., Graeve, M., van Franeker, J. A., Krumpen, T., and Flores, H.: Ice algae-produced carbon is critical for overwintering of Antarctic krill Euphausia superba,Front. Mar. Sci., 4, 310, https://doi.org/10.3389/fmars.2017.00310, 2017.

Korb, R. E., Whitehouse, M. J., Thorpe, S. E., and Gordon M.: Primary production across the Scotia Sea in relation to the physic-chemical environment, J. Mar. Syst., 57, 231-249, https://doi.org/10.1016/j.jmarsys.2005.04.009, 2005.

Kottmeier, S. T. and Sullivan, C. W., Late winter primary production and bacterial production in sea ice and seawater west of the Antarctic Peninsula, Mar. Ecol. Prog. Ser., 36, 287-298, https://doi.org/10.3354/meps036287, 1987.

Lancelot, C., Mathot, S., Veth, C., and de Baar, H.: Factors controlling phytoplankton ice-edge blooms in the marginal ice-zone of the northwestern Weddell Sea during sea ice retreat 1988: field observations and mathematical modelling, Polar Biol., 13, $377-$ 387, 1993.

Lannuzel, D., Schoemann, V., de Jong, J., Pasquer, B., van der Merwe, P., and Bowie, A. R.: Distribution of dissolved iron in Antarctic sea ice: spatial, seasonal and inter-annual variability, J. Geophys. Res., 115, G03022, https://doi.org/10.1029/2009JG001031, 2010.

Leu, E., Søreide, J. E., Hessen, D. O., Falk-Petersen, S., and Berge, J.: Consequences of changing sea-ice cover for primary and secondary producers in the European Arctic shelf seas: Timing, quantity, and quality, Prog. Oceanogr., 90, 18-32, https://doi.org/10.1016/j.pocean.2011.02.004, 2011.

Li, W. K. W., McLaughlin, F. A., Lovejoy, C., and Carmack, E. C.: Smallest algae thrive as the Arctic Ocean freshens, Science, 326, 539, https://doi.org/10.1126/science.1179798, 2009.

Marchese, C., Albouy, C., Tremblay, J.-E., Dumont, D., D’Ortenzio, F., Vissault, S., and Bélanger, S.: Changes in phytoplankton bloom phenology over the North Water (NOW) polynya: a re- 
sponse to changing environmental conditions, Polar Biol., 40, 1721-1737, https://doi.org/10.1007/s00300-017-2095-2, 2017.

Marschall, P.: The overwintering strategy of Antarctic krill under the pack ice of the Weddell Sea, Polar Biol., 34, 1887-1900, https://doi.org/10.1007/BF00442041, 1988.

Massé, G., Belt, S. T., Crosta, X., Schmidt, S., Snape, I., Thomas, D. N., and Rowland, S. J.: Highly branched isoprenoids as proxies for variable sea ice conditions in the Southern Ocean, Ant. Sci., 23, 487-498, https://doi.org/10.1017/S0954102011000381, 2011.

McMinn, A., Skerratt, J., Trull, T., Ashworth, C., and Lizotte, M.: Nutrient stress gradient in the bottom $5 \mathrm{~cm}$ of fast ice, McMurdo Sound, Antarctica, Polar. Biol., 21, 220-227, https://doi.org/10.1007/s003000050356, 1999.

Meier, W. N.: Losing Arctic sea ice: observations of the recent decline and the long-term context, in: Sea Ice, edited by: Thomas, D. N., John Wiley \& Sons, Ltd, Chichester, 290-303, https://doi.org/10.1002/9781118778371.ch11, 2017.

Meiners, K. M., Vancoppenolle, M., Thanassekos, S., Dieckmann, G. S., Thomas, D. N., Tison, J.-L., Arrigo, A. R., Garrison, D., McMinn, A., Lannuzel, D., van der Merwe, P., Swadling, K., Smith Jr., W. O., Melnikov, I., and Raymond, B.: Chlorophyll $a$ in Antarctic sea ice from historical ice core data, Geophys. Res. Lett., 39, L21602, https://doi.org/10.1029/2012GL053478, 2012.

Meyer, B., Fuentes, V, Guerra, C., Schmidt, K., Atkinson, A., Spahic, S., Cisewski, B, Freier, U, Olariaga, A., and Bathmann, U.: Physiology, growth, and development of larval krill Euphausia superba in autumn and winter in the Lazarev Sea, Antarctica, Limnol. Oceanogr., 54, 1595-1614, https://doi.org/10.4319/1o.2009.54.5.1595, 2009.

Meyer, B., Freier, U., Grimm, V., Groeneveld, J., Hunt, B. P. V., Kerwath, S., King, R., Klaas, C., Pakhomov, E. A., Meiners, K. M., Melbourne-Thomas, J., Murphy, E. J., Thorpe, S. E., Stammerjohn, S., Wolf-Gladrow, D., Auerswald, L., Götz, A., Halbach, L., Jarman, S., Kawaguchi, S., Krumpen, T., Nehrke, G., Ricker, R., Sumner, M., Teschke, M., Trebilco, R. and Yilmaz, I. N.: The winter pack-ice zone provides a sheltered but food-poor habitat for larval Antarctic krill, Nature Ecol. Evol., 1, 18531861https://doi.org/10.1038/s41559-017-0368-3, 2017.

Michel, C., Legendre, L., Ingram, R. G., Gosselin, M., and Levasseur, M.: Carbon budget of sea-ice algae in spring: Evidence of a significant transfer to zooplankton grazers, J. Geophys. Res., 101, 18345-18360, https://doi.org/10.1029/96JC00045, 1996.

Michels, J., Dieckmann, G. S., Thomas, D. N., Schnack-Schiel, S. B., Krell, A., Assmy, P., Kennedy, H., Papadimitriou, S., and Cisewski, B.: Short-term biogenic particle flux under late spring sea ice in the western Weddell Sea, Deep-Sea Res. II, 55, 1024 1039, https://doi.org/10.1016/j.dsr2.2007.12.019, 2008.

Montes-Hugo, M., Doney, S. C., Ducklow, H. W., Fraser, W., Martinson, D., Stammerjohn, S. E., and Schofield, O.: Recent changes in phytoplankton communities associated with rapid regional climate change along the western Antarctic Peninsula, Science, 323, 1470-1473, https://doi.org/10.1126/science.1164533, 2009.

Park, J., Oh, I.-S., Kim, H.-C., and Yoo, S.: Variability of SeaWiFs chlorophyll-a in the southwest Atlantic sector of the Southern Ocean: Strong topography effects and weak seasonality, Deep-Sea Res. I, 57, 604-620, https://doi.org/10.1016/j.dsr.2010.01.004, 2010.
Patrick, M. R., Smellie, J. L., Harris, A. J. L., Wright, R., Dean, K., Izbekov, P., Garbeil, H., and Pilger, E.: First recorded eruption of Mount Belinda volcano (Montagu Island), South Sandwich Islands, Bull. Volcanol., 67, 415-422, https://doi.org/10.1007/s00445-004-0382-6, 2005.

Perrette, M., Yool, A., Quartly, G. D., and Popova, E. E.: Nearubiquity of ice-edge blooms in the Arctic, Biogeosciences, 8, 515-524, https://doi.org/10.5194/bg-8-515-2011, 2011.

Quetin, L. and Ross, R.: Episodic recruitment in Antarctic krill Euphausia superba in the Palmer LTER study region, Mar. Ecol Prog. Ser., 259, 185-200, https://doi.org/10.3354/meps259185, 2003.

Renaud, P. E., Riedel, A., Michel, C., Morata, N., Gosselin, M., Juul-Pedersen, T., and Chiuchiolo, A.: Seasonal variations in the benthic community oxygen demand: a response to an ice algal bloom in the Beaufort Sea, Canadian Arctic, J. Mar. Syst., 67, 1-12, https://doi.org/10.1016/j.jmarsys.2006.07.006, 2007.

Ribeiro, S., Sejr, M. K., Limoges, A., Heikkilä, M., Andersen, T. J., Tallberg, P., Weckström, K., Husum, K., Forwick, M., Dalsgaard, T., Massé, G., Seidenkrantz, M.-S., and Rysgaard, S.: Sea ice and primary production proxies in surface sediments from a High Arctic Greenland fjord: spatial distribution and implications for palaeo-environmental studies, Ambio 46, 106-118, https://doi.org/10.1007/s13280-016-0894-2, 2017.

Riebesell, U., Schloss, I., and Smetacek, V.: Aggregation of algae released from melting sea ice: implications for seeding and sedimentation, Polar Biol., 11, 239-248, 1991.

Ross, R. M., Quetin, L. B., Baker, K. S., Vernet, M., and Smith, R. C.: Growth limitation in young Euphausia superba under field conditions, Limnol. Oceanogr., 45, 31-43, https://doi.org/10.4319/lo.2000.45.1.0031, 2000.

Roukaerts, A., Cavagna, A.-J., Fripiat, F., Lannuzel, D., Meiners, K. M., and Dehairs, F.: Sea-ice algal primary production and nitrogen uptake off East Antarctica, Deep-Sea Res. II, 131, 140-149, https://doi.org/10.1016/j.dsr2.2015.08.007, 2016.

Ryabov, A. B., de Ross, A. M., Meyer, B., Kawaguchi, S., and Blasius, B.: Competition-induced starvation drives large-scale population cycles in Antarctic krill, Nat. Ecol. Evol., 1, 0177, https://doi.org/10.1038/s41559-017-0177, 2017.

Saba, G. K., Fraser, W. R., Saba, V. S., Iannuzzi, R. A., Coleman, K. E., Doney, S. C., Ducklow, H. W., Martinson, D. G., Miles, T. N., Patterson-Fraser, D. L., Stammerjohn, S. E., Steinberg, D. K., and Schofield, O. M.: Winter and spring controls on the summer food web of the coastal West Antarctic Peninsula, Nat. Comms., 5, 4318, https://doi.org/10.1038/ncomms5318, 2014.

Schallenberg, C., van der Merwe, P., Chever, F., Cullen, J. T., Lannuzel, D., and Bowie, A. R.: Dissolved iron and iron(II) distributions beneath the pack ice in the East Antarctic $\left(120^{\circ} \mathrm{E}\right)$ during the winter/spring transition, Deep-Sea Res. II, 131, 96-110, https://doi.org/10.1016/j.dsr2.2015.02.019, 2015.

Schlitzer, R.: Ocean Data View, available at: http://odv.awi.de(last access: 1 December 2017), 2017.

Schmidt, K. and Atkinson, A.: Feeding and food processing in Antarctic krill (Euphausia superba Dana), in: Biology and Ecology of Antarctic krill, edited by: Siegel, V., Adv. Polar Ecol., https://doi.org/10.1007/978-3-319-29279-3_5, 2016.

Schmidt, K., Atkinson, A., Petzke, K. J., Voss, M., and Pond, D. W.: Protozoans as a food source for Antarctic krill, Euphausia superba: complementary insights from stomach content, fatty 
acids, and stable isotopes, Limnol. Oceanogr., 51, 2409-2427, https://doi.org/10.4319/lo.2006.51.5.2409, 2006.

Schmidt, K., Atkinson, A., Steigenberger, S., Fielding, S., Lindsay, M. C. M., Pond, D. W., Tarling, G. A., Klevjer, T. A., Allen, C. S., Nicol, S., and Achterberg, E. P.: Seabed foraging by Antarctic krill: Implications for stock assessment, bentho-pelgic coupling and the vertical transfer of iron, Limnol. Oceanogr., 56, 14111428, https://doi.org/10.4319/lo.2011.56.4.1411, 2011.

Schmidt, K., Atkinson, A., Venables, H. J., and Pond, D. W.: Early spawning of Antarctic krill in the Scotia Sea is fuelled by "superfluous" feeding on non-ice associated phytoplankton blooms, Deep-Sea Res. II, 59-60, 159-172, https://doi.org/10.1016/j.dsr2.2011.05.002, 2012.

Schmidt, K., Atkinson, A., Pond, D. W., and Ireland, L. C.: Feeding and overwintering of Antarctic krill across its major habitats: The role of sea ice cover, water depth, and phytoplankton abundance, Limnol. Oceanogr., 59, 17-36, https://doi.org/10.4319/lo.2014.59.1.0017, 2014.

Schmidt, K., Schlosser, C., Atkinson, A., Fielding, S., Venables, H. J., Waluda, C. M., and Achterberg, E. P.: Zooplankton gut passage mobilizes lithogenic iron for ocean productivity, Current Biol., 26, 1-7, https://doi.org/10.1016/j.cub.2016.07.058, 2016.

Smetacek, V. and Nicol, S.: Polar ocean ecosystems in a changing world, Nature, 437, 363-368, https://doi.org/10.1038/nature04161, 2005.

Smik, L., Belt, S. T., Lieser, J. L., Armand, L. K., and Leventer, A.: Distributions of highly branched isoprenoid alkenes and other algal lipids in surface waters from East Antarctica: Further insights for biomarker-based paleo sea-ice reconstruction, Org. Geochem., 95, 71-80, https://doi.org/10.1016/j.orggeochem.2016.02.011, 2016.

Smith Jr., W. O. and Nelson, D. M.: The importance of iceedge blooms in the Southern Ocean, Biosciences, 36, 251-257, https://doi.org/10.2307/1310215, 1986.

Søreide, J. E., Leu, E., Berge, J., Graeve, M., and FalkPetersen, S.: Timing of blooms, algal food quality and Calanus glacialis reproduction and growth in a changing Arctic, Glob. Change Biol. 16, 3154-3163, https://doi.org/10.1111/j.13652486.2010.02175.x, 2010.

Spreen, G., Kaleschke, L., and Heygster, G.: Sea ice remote sensing using AMSR-E $89 \mathrm{GHz}$ channels, J. Geophys. Res., 113, C02S03, https://doi.org/10.1029/2005JC003384, 2008.
Stammerjohn, S. and Maksym, T.: Gaining (and losing) Antarctic sea ice: variability, trends and mechanisms, in: Sea Ice, edited by: Thomas D. N., John Wiley \& Sons, Ltd, Chichester, 261289, https://doi.org/10.1002/9781118778371.ch10, 2017.

Stammerjohn, S., Massom, R., Rind, D., and Martinson, D.: Regions of rapid sea ice change: An inter-hemispheric seasonal comparison, Geophys. Res. Lett, 39, L06501, https://doi.org/10.1029/2012GL050874, 2012.

Tréguer, P. and Jacques, G.: Dynamics of nutrients and phytoplankton, and fluxes of carbon, nitrogen and silicon in the Antarctic Ocean, Polar. Biol., 12, 149-169, 1992.

Vancoppenolle, M., Meiners, K. M., Michel, C., Bopp, L., Brabant, F., Carbat, G., Delille, B., Lannuzel, D., Madec, G., Moreau, S., Tison, J.-L., and van der Merwe, P.: Role of sea ice in global biogeochemical cycles: emerging views and challenges, Quat. Sci. Rev., 79, 207-230, https://doi.org/10.1016/j.quascirev.2013.04.011, 2013.

Venables, H. J., Clarke, A., and Meredith, M. P.: Wintertime controls on summer stratification and productivity at the western Antarctic Peninsula, Limnol. Oceanogr., 58, 1035-1047, https://doi.org/10.4319/lo.2013.58.3.1035, 2013.

Wang, S. W., Budge, S. M., Gradinger, R. R., Iken, K., and Wooller, M. J.: Fatty acid and stable isotope characteristics of sea ice and pelagic particulate organic matter in the Bering Sea: tools for estimating sea ice algal contribution to Arctic food web production, Oecolog., 174, 699-712, https://doi.org/10.1007/s00442013-2832-3, 2014.

Wang, S. W., Budge, S. M., Iken, K., Gradinger, R. R., Springer, A. M., and Wooller, M. J.: Importance of sympagic production to Bering Sea zooplankton as revealed from fatty acidcarbon stable isotope analyses, Mar. Ecol. Prog. Ser., 518, 31-50, https://doi.org/10.3354/meps11076, 2015.

Ward, P., Shreeve, R., Atkinson, K., Korb, R., Whitehouse, M., Thorpe, S., Pond, D., and Cunnigham, N.: Plankton community structure and variability in the Scotia Sea: austral summer 2003, Mar. Ecol. Prog. Ser., 309, 75-91, https://doi.org/10.3354/meps309075, 2006.

Wassmann, P., Duarte, C. M., Agusti, S., and Sejr, M. K.: Footprints of climate change in the Arctic marine ecosystem, Glob Change Biol., 17, 1235-1249, https://doi.org/10.1111/j.13652486.2010.02311.x, 2011. 